\title{
Diversity of freshwater dinoflagellates in the State of Paraná, southern Brazil, with taxonomic and distributional notes
}

\author{
Kaoli P. Cavalcante ${ }^{*}$, Sandra C. Craveiro², António J. Calado ${ }^{2}$, Thelma A. V. \\ LudwiG $^{3} \&$ Luciana de S. CARDOSO ${ }^{1}$
}

\begin{abstract}
${ }^{1}$ Postgraduate Program in Botany, Department of Botany, Federal University of Rio Grande do Sul, Porto Alegre-RS, Brazil; *Corresponding authore-mail: kaolicavalcante@gmail.com

${ }^{2}$ Department of Biology and GeoBioTec Research Unit, University of Aveiro, P-3810-193 Aveiro, Portugal

${ }^{3}$ Department of Botany, Federal University of Paraná, Curitiba-PR, Brazil
\end{abstract}

\begin{abstract}
Dinoflagellate taxonomy has been undergoing a comprehensive review in recent decades. Knowledge on Brazilian dinoflagellate flora remains quite incomplete, particularly regarding the size of the country. This study is the first taxonomic survey of freshwater dinoflagellates in the State of Paraná, southern Brazil. Fortyone freshwater environments were sampled in Paraná and two others on the border between Paraná and Santa Catarina during 2010-2015, and 21 dinoflagellate taxa assigned to 13 genera were identified and described based on light (LM) and scanning electron (SEM) microscopy. A new combination is proposed: Parvodinium africanum var. javanicum comb. nov. Three taxa are new records for Brazilian freshwaters: Glenodiniopsis uliginosa, P. africanum var. javanicum and Tyrannodinium edax. Taxonomic and nomenclatural comments about the recorded species as well as their known distribution in Brazil are also given.
\end{abstract}

Key words: Dinophyceae, light microscopy, morphology, scanning electron microscopy, South America, taxonomy

\section{INTRODUCTION}

The taxonomy of freshwater dinoflagellates has been extensively revised in recent decades (Moestrup \& DAUGBJerg 2007). Modern integration of molecular, ultrastructural, and life cycle studies, combined with the traditional morphological knowledge, has led to a number of nomenclatural changes, new generic propositions, and a redefinition of the phylogenetic relationships among the taxa. Such revision was essentially based on populations sampled in Europe (e.g. CALADO et al. 2009; Craveiro et al. 2010; Mertens et al. 2015), Asia (TAKano \& Horiguchi 2004; Zhang et al. 2011; TAKANO et al. 2014), and North America (FAwCETT \& PARROW 2012). Little information was added about tropical/subtropical dinoflagellates from the Southern Hemisphere (Boltovskoy 1999; Pearce \& HalLEGRAEFF 2004).

Freshwater dinoflagellate species from Brazil are poorly known. The majority of the citations lack detailed morphological information. The first reference to a dinoflagellate collected in Brazil was from Rodrigo de Freitas Lagoon, State of Rio de Janeiro, made by MöBIUs (1889), describing Peridinium tabu- latum f. brasilianum Möвıus ('brasiliana'; reinterpreted as Bysmatrum subsalsum (Ostenfeld) Faust et Steidinger by Popovský \& Pfiester 1990). In the first half of the $20^{\text {th }}$ century, studies on protozoofauna (dinoflagellates were then considered from a zoological viewpoint) identified some dinoflagellate species ( $\mathrm{D}_{\mathrm{A}}$ Day 1905; Prowazek 1910; Cunha 1913; 1916; 1918; KLEEREKOPER 1939). With a gap of almost 30 years, new records of this group were made in southeastern (Bicudo \& Bicudo 1967; 1969; Bicudo \& SkVORTZOV 1968; 1970; Bicudo \& Ventrice 1968) and northern Brazil (Uherkovich \& Schmidt 1974; Uherkovich 1976; 1981; UhERKOVICH \& RAI 1979; Uherkovich \& Franken 1980). More recent and important studies on the dinoflagellate flora include Meyer et al. (1997), who described Peridiniopsis amazonica Meyer from Amazonian lakes; Borics et al. (2005), who listed dinoflagellate species in tropical lakes from southeastern Brazil and proposed the new species Peridinium brasiliense Borics et Grigorszky (Menezes \& Fernandes 1990; Menezes 1995; Menezes et al. 1995; ALBuquerque \& Menezes 1997; Cardoso \& Torgan 2007; CARDOSo et al. 2010), all of whom added new records to the dinoflagellate flora from northern to southern 
Brazil; and finally the recent records of the invasive Ceratium Schrank spp. in Brazil (SANTOS-WisNiEwSKI et al. 2007; Matsumura-Tundisi et al. 2010; Oliveira et al. 2011; CAVAlCANTE et al. 2013; JATI et al. 2014). Other anomalous dinoflagellate records can be found scattered in general lists of freshwater phytoplankton (e.g. Huszar et al. 1988; SANT'AnNa et al. 1988; FranCESChINI 1992; Huszar 1996; Delazari-Barroso et al. 2007). As a result, knowledge of the distribution of dinoflagellates in Brazil is fairly limited, geographically narrow, and confined to the most common species. Rio de Janeiro (20 spp. recorded), São Paulo (14 spp.), and Rio Grande do Sul (12 spp.) are the states with the highest number of recorded species (ODEBRECHT et al. 2015), whereas only two species were registered in the State of Paraná, southern Brazil: Peridinium gatunense Nygaard (Odebrecht et al. 2015) and Ceratium furcoides (LeVAnder) Langhans (CAVAlcante et al. 2013; JATI et al. 2014).

In this study, we performed an extensive dinoflagellate floristic survey in 43 distinct freshwater environments of Paraná (two in Santa Catarina), including reservoirs, natural and urban artificial lakes, and lakes formed in abandoned quarries. Records given here take into account taxonomic name changes that resulted from our current knowledge of dinoflagellate systematics.

\section{Materials And Methods}

Forty-one water bodies from State of Paraná were sampled between 2010 and 2015 (Fig. 1, Table 1). The majority of the reservoirs (localities 1-18, Table 1) were sampled quarterly between February 2011 and May 2013. The quarry lakes were sampled over three periods (localities 34-39, Table 1), while the other environments were sampled less frequently, resulting in 209 samples containing dinoflagellates. Two sample sites were in the State of Santa Catarina (localities
42, 43, Table 1), close to the border with Paraná; these were included in this study due to being in the geographical area of interest.

Plankton was collected using a $20-\mu \mathrm{m}$ mesh plankton net. Submerged parts of marginal macrophytes were also sampled when present and the periphyton attached were removed by squirting. Live samples were taken to the laboratory and observed as soon as possible and subsamples were preserved with Lugol's solution, $4 \%$ formaldehyde, or $2-3 \%$ glutaraldehyde. Dinoflagellates were identified, measured, and photographed with the light microscopes (LM) Olympus BX-40, equipped with Olympus DP71 digital camera, and Zeiss Axioplan 2, equipped with DP70 and ColorView IIIu digital cameras. Some epifluoresence observations were performed with CalcoFluor White-stained cells according to Fritz \& Triemer (1985). For scanning electron microscopy (SEM), two treatments were used: preserved field samples (1) were settled in Poly-L-Lysine coated coverslips or (2) were filtered in Nuclepore polycarbonate membrane filters with 2-8 $\mu \mathrm{m}$ pore size; in both techniques, samples were subsequently washed in distilled water, dehydrated through a graded ethanol series, and critical point dried in a BALTEC CPD 030. Filters and coverslips were sputter-coated with gold or gold-palladium and examined with a Jeol JSM 6360LV or a Hitachi S-4100 scanning electron microscope, located at Electron Microscopy Center of the Federal University of Paraná, Brazil, and Department of Materials and Ceramic Engineering of the University of Aveiro, Portugal, respectively. Vouchers of selected samples were stored in the herbarium of the Federal University of Paraná (UPCB, Table 1). Identification followed standard floras (LeFĖVRE 1932; Schiller 1937; Huber-Pestalozzi 1950; Popovský \& PfiesTER 1990), always checked against original publications and recent reviews of the taxa. Descriptions of taxa were based only on features that could be observed in our material; details of plate tabulation that were not confirmed in our material are indicated with a question mark (?). No classification system was adopted, since a deep revision of this group at higher taxonomic levels is needed (Moestrup \& DAUGBJerG 2007). However, the alphabetically arranged taxa were assembled into three major morphological groups: naked and thin-walled species; thecate species; and immobile species.

Table 1. List of sampling localities and dates. Vouchers of selected samples were stored in the herbarium (UPCB).

\begin{tabular}{|c|c|c|c|c|}
\hline Code & Locality, City & Coordinates & Dates & $\begin{array}{l}\text { Herbarium } \\
\text { Code (UPCB) }\end{array}$ \\
\hline 1 & Capivari reservoir, Antonina & $25^{\circ} 08^{\prime} 27^{\prime \prime} \mathrm{S}, 48^{\circ} 52^{\prime} 21^{\prime \prime} \mathrm{W}$ & Apr/11-Apr/13 & $\begin{array}{l}68867,72237, \\
78155\end{array}$ \\
\hline 2 & Guaricana reservoir, Guaratuba & $25^{\circ} 42^{\prime} 39^{\prime \prime} \mathrm{S}, 48^{\circ} 58^{\prime} 16^{\prime \prime} \mathrm{W}$ & Feb/11-May/13 & $\begin{array}{l}68875,72245, \\
78163\end{array}$ \\
\hline 3 & $\begin{array}{l}\text { Chaminé reservoir, São José dos Pin- } \\
\text { hais }\end{array}$ & $25^{\circ} 49^{\prime} 19^{\prime \prime} \mathrm{S}, 49^{\circ} 03^{\prime} 58^{\prime \prime} \mathrm{W}$ & $\mathrm{Feb} / 11-\mathrm{Feb} / 13$ & $\begin{array}{l}68869,72239 \\
78157\end{array}$ \\
\hline 4 & $\begin{array}{l}\text { Salto Caxias reservoir, Cap. Leônidas } \\
\text { Marques }\end{array}$ & $25^{\circ} 32^{\prime} 10^{\prime \prime} \mathrm{S}, 53^{\circ} 29^{\prime} 31^{\prime \prime} \mathrm{W}$ & Feb/11-May/13 & $\begin{array}{l}68882,72252 \\
78170\end{array}$ \\
\hline 5 & Cavernoso reservoir, Virmond & $25^{\circ} 29^{\prime} 32^{\prime \prime} \mathrm{S}, 52^{\circ} 12^{\prime} 53^{\prime \prime} \mathrm{W}$ & Mar/11-Mar/13 & $\begin{array}{l}68868,72238 \\
78156\end{array}$ \\
\hline 6 & Segredo reservoir, Mangueirinha & $25^{\circ} 47^{\prime} 37^{\prime \prime} \mathrm{S}, 52^{\circ} 06^{\prime} 54^{\prime \prime} \mathrm{W}$ & Mar/11-Mar/13 & $\begin{array}{l}68886,72256 \\
78174\end{array}$ \\
\hline
\end{tabular}


Table 1 Cont.

\begin{tabular}{|c|c|c|c|c|}
\hline 7 & Jordão reservoir, Reserva do Iguaçu & $25^{\circ} 45^{\prime} 16^{\prime \prime} \mathrm{S}, 52^{\circ} 04^{\prime} 56^{\prime \prime} \mathrm{W}$ & Apr/11-Apr/13 & $\begin{array}{l}68876,72246, \\
78164\end{array}$ \\
\hline 8 & Santa Clara reservoir, Pinhão & $25^{\circ} 38^{\prime} 59^{\prime \prime} \mathrm{S}, 51^{\circ} 56^{\prime} 55^{\prime \prime} \mathrm{W}$ & Apr/11-Mar/13 & $\begin{array}{l}68887,72257, \\
78176\end{array}$ \\
\hline 9 & Fundão reservoir, Pinhão & $25^{\circ} 41^{\prime} 57^{\prime \prime} \mathrm{S}, 51^{\circ} 59^{\prime} 58^{\prime \prime} \mathrm{W}$ & Apr/11-Mar/13 & $\begin{array}{l}68888,72258, \\
78177\end{array}$ \\
\hline 10 & Foz do Areia reservoir, Pinhão & $26^{\circ} 00^{\prime} 30^{\prime \prime} \mathrm{S}, 51^{\circ} 39^{\prime} 48^{\prime \prime} \mathrm{W}$ & $\mathrm{Feb} / 11-\mathrm{Apr} / 13$ & $\begin{array}{l}68873,72243 \\
78161\end{array}$ \\
\hline 11 & $\begin{array}{l}\text { Salto do Vau reservoir, União da } \\
\text { Vitória }\end{array}$ & $26^{\circ} 02^{\prime} 05^{\prime \prime} \mathrm{S}, 51^{\circ} 11^{\prime} 06^{\prime \prime} \mathrm{W}$ & Mar/11-Mar/13 & $\begin{array}{l}68883,72253, \\
78171\end{array}$ \\
\hline 12 & Chopim reservoir, Itapejara d'Oeste & $25^{\circ} 59^{\prime} 19^{\prime \prime} \mathrm{S}, 52^{\circ} 44^{\prime} 47^{\prime \prime} \mathrm{W}$ & Mar/11-Mar/13 & $\begin{array}{l}68871,72241, \\
78159\end{array}$ \\
\hline 13 & Melissa reservoir, Corbélia & $24^{\circ} 32^{\prime} 14^{\prime \prime} \mathrm{S}, 53^{\circ} 12^{\prime} 30^{\prime \prime} \mathrm{W}$ & Mar/11-Mar/13 & $\begin{array}{l}68877,72247, \\
78165\end{array}$ \\
\hline 14 & Mourão reservoir, Campo Mourão & $24^{\circ} 06^{\prime} 23^{\prime \prime} \mathrm{S}, 52^{\circ} 19^{\prime} 44^{\prime \prime} \mathrm{W}$ & Mar/11-Mar/13 & $\begin{array}{l}68878,72248, \\
78166\end{array}$ \\
\hline 15 & Rio dos Patos reservoir, Prudentópolis & $25^{\circ} 10^{\prime} 11^{\prime \prime} \mathrm{S}, 50^{\circ} 56^{\prime} 39^{\prime \prime} \mathrm{W}$ & May/11-May/13 & $\begin{array}{l}68880,72250, \\
78168\end{array}$ \\
\hline 16 & Apucaraninha reservoir, Tamarana & $23^{\circ} 45^{\prime} 01^{\prime \prime S}, 50^{\circ} 56^{\prime} 28^{\prime \prime} \mathrm{W}$ & Jun/11-May/13 & $\begin{array}{l}68866,72236, \\
78154\end{array}$ \\
\hline 17 & Pitangui reservoir, Ponta Grossa & $25^{\circ} 01^{\prime} 43^{\prime \prime} \mathrm{S}, 50^{\circ} 06^{\prime} 10^{\prime \prime} \mathrm{W}$ & Apr/11-Apr/13 & $\begin{array}{l}68879,72249 \\
78167\end{array}$ \\
\hline 18 & São Jorge reservoir, Ponta Grossa & $25^{\circ} 01^{\prime} 06^{\prime \prime} \mathrm{S}, 50^{\circ} 03^{\prime} 40^{\prime \prime} \mathrm{W}$ & Apr/11-Apr/13 & $\begin{array}{l}68884,72254 \\
78172\end{array}$ \\
\hline 19 & Piraquara II reservoir, Piraquara & $25^{\circ} 29^{\prime} 37^{\prime \prime} \mathrm{S}, 49^{\circ} 05^{\prime} 13^{\prime \prime} \mathrm{W}$ & May-Nov/13 & 78194 \\
\hline 20 & Irai reservoir, Pinhais & $25^{\circ} 23^{\prime} 58^{\prime \prime} \mathrm{S}, 49^{\circ} 05^{\prime} 52^{\prime \prime} \mathrm{W}$ & Jan-Apr/13 & 78179 \\
\hline 21 & $\begin{array}{l}\text { Smaller lake in São José dos Pinhais } \\
\text { Urban Park, São José dos Pinhais }\end{array}$ & $25^{\circ} 30^{\prime} 42^{\prime \prime} \mathrm{S}, 49^{\circ} 12^{\prime} 12^{\prime \prime} \mathrm{W}$ & $\begin{array}{l}\text { Nov/11, Nov/12, Apr/13, } \\
\text { Aug/14, Nov/14 }\end{array}$ & $78180-78185$ \\
\hline 22 & $\begin{array}{l}\text { Larger lake in São José dos Pinhais } \\
\text { Urban Park, São José dos Pinhais }\end{array}$ & $25^{\circ} 30^{\prime} 43^{\prime \prime} \mathrm{S}, 49^{\circ} 12^{\prime} 11^{\prime \prime} \mathrm{W}$ & $\begin{array}{l}\text { Nov/11, Nov/12, Apr/13, } \\
\text { Aug/14, Nov/14 }\end{array}$ & $78186-78190$ \\
\hline 23 & $\begin{array}{l}\text { Lake in Passeio Público Urban Park, } \\
\text { Curitiba }\end{array}$ & $25^{\circ} 25^{\prime} 32^{\prime \prime} \mathrm{S}, 49^{\circ} 16^{\prime} 06^{\prime \prime} \mathrm{W}$ & Sep/14 & 78191 \\
\hline 24 & Lake in Barigui Urban Park, Curitiba & $25^{\circ} 25^{\prime} 45^{\prime \prime} \mathrm{S}, 49^{\circ} 18^{\prime} 51^{\prime \prime} \mathrm{W}$ & Sep/12 & - \\
\hline 25 & $\begin{array}{l}\text { Lake in São Lourenço Urban Park, } \\
\text { Curitiba }\end{array}$ & $25^{\circ} 23^{\prime} 03^{\prime \prime} \mathrm{S}, 49^{\circ} 15^{\prime} 56^{\prime \prime} \mathrm{W}$ & Sep/15 & - \\
\hline 26 & Lake in Tanguá Urban Park, Curitiba & $25^{\circ} 22^{\prime} 46^{\prime \prime} \mathrm{S}, 49^{\circ} 17^{\prime} 05^{\prime \prime} \mathrm{W}$ & $\mathrm{Jan} / 14$ & - \\
\hline 27 & Urban lake in Unilivre, Curitiba & $25^{\circ} 23^{\prime} 48^{\prime \prime} \mathrm{S}, 49^{\circ} 17^{\prime} 00^{\prime \prime} \mathrm{W}$ & $\operatorname{Mar} / 14$ & - \\
\hline 28 & $\begin{array}{l}\text { Lake in Barreirinha Urban Park, } \mathrm{Cu}- \\
\text { ritiba }\end{array}$ & $25^{\circ} 21^{\prime} 42^{\prime \prime} \mathrm{S}, 49^{\circ} 15^{\prime} 33^{\prime \prime} \mathrm{W}$ & Mar/14 & - \\
\hline 29 & $\begin{array}{l}\text { Urban lake in Ópera de Arame, Curi- } \\
\text { tiba }\end{array}$ & $25^{\circ} 23^{\prime} 05^{\prime \prime} \mathrm{S}, 49^{\circ} 16^{\prime} 33^{\prime \prime} \mathrm{W}$ & $\begin{array}{l}\text { Oct } / 10, \mathrm{Jan} / 13, \mathrm{Mar} / 14, \\
\text { Aug/14 }\end{array}$ & 78192 \\
\hline 30 & $\begin{array}{l}\text { Urban lake in Paulo Leminski Quarry, } \\
\text { Curitiba }\end{array}$ & $25^{\circ} 23^{\prime} 05^{\prime \prime} \mathrm{S}, 49^{\circ} 16^{\prime} 41^{\prime \prime} \mathrm{W}$ & Sep/14, Mar/14, Dec/14 & $\begin{array}{l}76054,78193 \\
78214\end{array}$ \\
\hline 31 & Azul lake, Paranaguá & $25^{\circ} 32^{\prime} 17^{\prime \prime} \mathrm{S}, 48^{\circ} 34^{\prime} 10^{\prime \prime} \mathrm{W}$ & Dec/11 & 75223 \\
\hline 32 & $\begin{array}{l}\text { Lake in Aníbal Khury Urban Park, } \\
\text { Almirante Tamandaré }\end{array}$ & $25^{\circ} 19^{\prime} 42^{\prime \prime} \mathrm{S}, 49^{\circ} 17^{\prime} 35^{\prime \prime} \mathrm{W}$ & Sep/14, Dec/14 & 78197,78198 \\
\hline 33 & $\begin{array}{l}\text { Luís Mussi Lake, in Aníbal Khury } \\
\text { Urban Park, Almirante Tamandaré }\end{array}$ & $25^{\circ} 19^{\prime} 09^{\prime \prime} \mathrm{S}, 49^{\circ} 17^{\prime} 33^{\prime \prime} \mathrm{W}$ & Sep/14, Dec/14 & 78199,78200 \\
\hline
\end{tabular}


Table 1 Cont

\begin{tabular}{|c|c|c|c|c|}
\hline 34 & $\begin{array}{l}\text { Urban lake in Parque Ecológico da } \\
\text { Lagoa Grande, Campo Largo }\end{array}$ & $25^{\circ} 26^{\prime} 41^{\prime \prime S}, 49^{\circ} 31^{\prime} 55^{\prime \prime} \mathrm{W}$ & Jan/12, Sep/14, Dec/14 & $\begin{array}{l}76043,78201, \\
78202\end{array}$ \\
\hline 35 & $\begin{array}{l}\text { Lake in Cambuí Urban Park, Campo } \\
\text { Largo }\end{array}$ & $25^{\circ} 28^{\prime} 27^{\prime \prime S}, 49^{\circ} 31^{\prime} 46^{\prime \prime} \mathrm{W}$ & Jan/12, Sep/14, Dec/14 & $\begin{array}{l}76041,78203, \\
78204\end{array}$ \\
\hline 36 & Quarry lake, Campo Magro & $25^{\circ} 24^{\prime} 35^{\prime \prime} \mathrm{S}, 49^{\circ} 22^{\prime} 48^{\prime \prime} \mathrm{W}$ & Jan/12, Sep/14 & 76039,78205 \\
\hline 37 & $\begin{array}{l}\text { Lake in Sand mining region, Campo } \\
\text { Largo }\end{array}$ & $25^{\circ} 24^{\prime} 30^{\prime \prime} \mathrm{S}, 49^{\circ} 33^{\prime} 50^{\prime \prime} \mathrm{W}$ & Jan/12, Sep/14, Dec/14 & $\begin{array}{l}76045,78206, \\
78207\end{array}$ \\
\hline 38 & Quarry lake, Campo Magro & $25^{\circ} 19^{\prime} 29^{\prime \prime S}, 49^{\circ} 27^{\prime} 17^{\prime \prime} \mathrm{W}$ & Jan/12, Sep/14, Dec/14 & $\begin{array}{l}76046,78208, \\
78209\end{array}$ \\
\hline 39 & Quarry lake, Campo Magro & $25^{\circ} 19^{\prime} 34^{\prime \prime S}, 49^{\circ} 27^{\prime} 36^{\prime \prime} \mathrm{W}$ & $\mathrm{Sep} / 14, \mathrm{Dec} / 14$ & 78210,78211 \\
\hline 40 & $\begin{array}{l}\text { Lake in Pousada Recanto dos Lagos, } \\
\text { Mandirituba }\end{array}$ & $25^{\circ} 47^{\prime} 58^{\prime \prime} \mathrm{S}, 49^{\circ} 16^{\prime} 38^{\prime \prime} \mathrm{W}$ & May/15 & - \\
\hline 41 & $\begin{array}{l}\text { Lake in Pousada Recanto dos Lagos, } \\
\text { Mandirituba }\end{array}$ & $25^{\circ} 47^{\prime} 59^{\prime \prime} \mathrm{S}, 49^{\circ} 16^{\prime} 34^{\prime \prime} \mathrm{W}$ & May/15 & - \\
\hline 42 & $\begin{array}{l}\text { River in Recanto Pe. Francisco Hable } \\
\text { Park, Mafra-SC }\end{array}$ & $26^{\circ} 08^{\prime} 22^{\prime \prime S}, 49^{\circ} 53^{\prime} 30^{\prime \prime} \mathrm{W}$ & $\mathrm{Jan} / 12$ & 78195 \\
\hline 43 & $\begin{array}{l}\text { Small lake in Recanto Pe. Francisco } \\
\text { Hable Park, Mafra-SC }\end{array}$ & $26^{\circ} 08^{\prime} 07^{\prime \prime S}, 49^{\circ} 53^{\prime} 24^{\prime \prime} \mathrm{W}$ & $\operatorname{Jan} / 12$ & 78196 \\
\hline
\end{tabular}

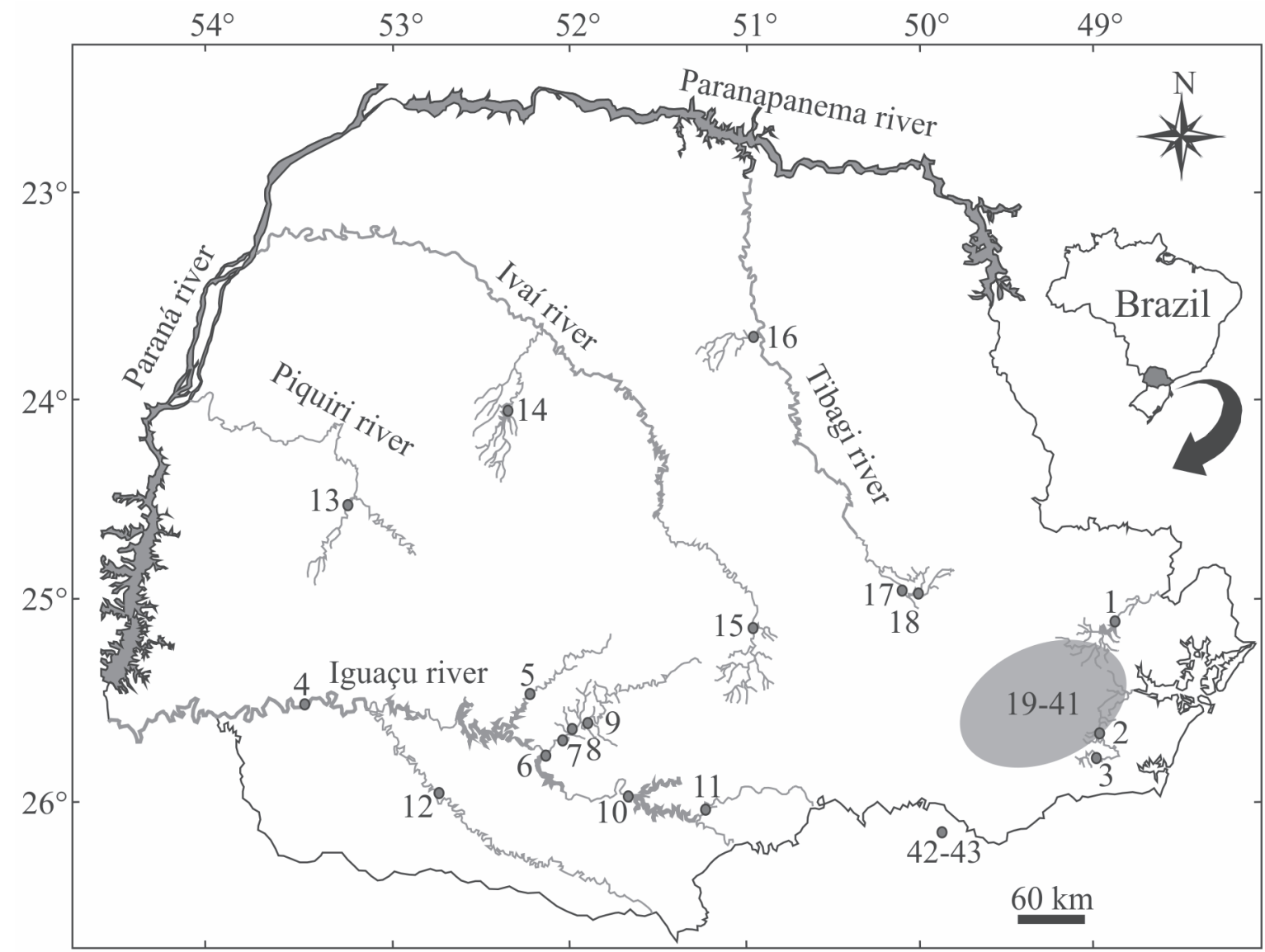

Fig. 1. Sampling localities in the State of Paraná. Numbers are described in Table 1 as Code. Numbers 42 and 43 are located in the State of Santa Catarina (see text). 


\section{Results AND Discussion}

Naked and thin-walled, planktonic dinoflagellates

Gymnodinium fuscum (EHrenberg) F. STEIn (1878, p. 95) Figs $2-4$

Basionym: Peridinium fuscum EHRenBerg (1834, p. 270)

Large cells, dorsoventrally flattened; epicone typically round, sometimes tapering to a narrow apex (Fig. 3), hypocone apiculate, cingulum median; brown plastids, radially arranged; nucleus in epicone; eyespot not observed. Spherical cysts with irregular external wall and large accumulation body positioned in the center. Length: 38-64 $\mu \mathrm{m}$; width: 20-37.4 $\mu \mathrm{m}$.

Occurrence (see codes for localities in Table 1): 2, $3,7,8,9,10,14,16,17,19,21,22$. It was observed at various times of the year.

Comments: we have found populations with smaller cells than commonly reported (e.g. PopovskÝ \& PfiesTer 1990; Hansen \& Flaim 2007; CarTy 2014), bringing to mind G. fuscum var. minus VILLERET 'minor' (VILlERET 1953). However, populations with similar size have been referred to as G. fuscum by THOMPSON (1947), Dodge \& Crawford (1969), and Senzaki \& Horiguchi (1994).

Distribution in Brazil: States of Rio de Janeiro (CunHA 1913; 1916) and São Paulo (BICUdo \& Skvortzov 1970). This is the first record for southern Brazil.

Gymnodinium mirabile Penard (1891, p. 56, pl. V, figs 1-7) Figs 5-7

Large cells, dorsoventrally flattened; epicone round to bell shaped, hypocone flattened at the antapex, smaller than the epicone; cingulum slightly descending; sulcus narrow, extending into the epicone; brown plastids, radially arranged; sometimes with a hyaline area along the cell surface; large central nucleus; eyespot not observed; vegetative division was commonly observed (Fig. 7). Length: 30-65 $\mu \mathrm{m}$; width: $22.5-57.5 \mu \mathrm{m}$.

Occurrence: localities 2, 6, 7, 8, 9, 10, 16, 19, 37. It was observed at various times of the year.

Comments: Gymnodinium mirabile was originally described as being $90 \mu \mathrm{m}$ long and $65 \mu \mathrm{m}$ wide (PENARD 1891) but such large measurements were seldom reported afterwards. The same author described G. mirabile var. rufescens PENARD, a smaller and more rounded variety. Recent authors have used a broader concept for $G$. mirabile, including in this species smaller individuals, 40-70 $\mu \mathrm{m}$ long (HANSEN \& Flaim 2007; PANDEIRADA et al. 2013). Gymnodinium mirabile was regarded as synonym of G. uberrimum (Allman) KoFOID et Swezy in several floras (KofoId \& Swezy 1921; Popovský \& Pfiester 1990). However, the original description of G. uberrimum, without illustrations, is ambiguous, since its features fit more the current concept of woloszynskoid genera than that of a Gymnodinium species (AlLman 1854). Since both generic and specific circumscriptions of G. uberrimum are unclear we prefer to avoid this name.

Distribution in Brazil: there is only one record of $G$. mirabile in the coastal region of northern Brazil (WooD 1968). Bicudo \& Bicudo (1969) identified G. uberrimum in samples from Rio de Janeiro, and we take that record as also corresponding to G. mirabile. This is the first record of the species in southern Brazil.

Nusuttodinium aeruginosum (F. STEIN) Y. TAKANo et T. Horiguchi (2014, p. 773, figs 1M-R; 2H, I) Figs 8-10

Basionym: Gymnodinium aeruginosum F. SteIN (1883, pl. II, figs 19-22)

Ovoid cells, dorsoventrally flattened; epicone rounded or bell shaped, often smaller than the hypocone; hypocone rounded, antapex slightly flattened to somewhat tapering; cingulum slightly descending; sulcus narrow, extending into the epicone; numerous discoid green to blue-green plastids (interpreted as kleptoplastids of cryptomonad origin) throughout the cell; nucleus in epicone; eyespot not observed. Length: 26.7-44.6 $\mu \mathrm{m}$; width: $17.5-31.1 \mu \mathrm{m}$.

Occurrence: localities 19, 20, 21, 40, 41. It was observed at various times of the year.

Comments: Nusuttodinium acidotum (NygaArd) Y. TAKANO et T. Horiguchi and Gymnodinium eucyaneum H.J. Hu are closely related to $N$. aeruginosum. Some authors have considered them as conspecific (Popovský \& Pfiester 1990) while others have distinguished them mainly by the pointed antapex and by differences in relative size of epi- and hypocone (XIA et al. 2013). Based on molecular and morphological analysis, TAKANO et al. (2014) synonymized G. eucyaneum with $N$. acidotum but regarded $N$. aeruginosum as a separate species, pointing out that the number of longitudinal flagella and the typical form of a number of cells must be observed to identify a population with precision. Our populations fit $N$. aeruginosum morphospecies.

Distribution in Brazil: Rio de Janeiro (Menezes \& TEIXEIRA-JúnIOR 2001) and Rio Grande do Sul (ToRGAN et al. 2003). Early records of $G$. viride PENARD in Rio de Janeiro (CunHA 1913) and Porto Alegre (CunHA 1918) may perhaps correspond to $N$. aeruginosum, although this could not be confirmed due to lack of illustrations.

Hemidinium nasutum F. STEIN (1878, pp. 91, 97; first illustrated in STEIN 1883, pl. II, figs 23-26) Figs 11, 12

Elliptical cells, dorsoventrally flattened; epi- and hypocone ovoid; cingulum median, incomplete, present only on the left side of the cell; elongated yellowbrown plastids, radially arranged; nucleus in hypotheca; eyespot not observed; reddish accumulation bodies often seen in epitheca. The thin thecal tabulation commonly reported for this species was not detected. Length: $24.4-32.5 \mu \mathrm{m}$; width: 15.2-20 $\mu \mathrm{m}$.

Occurrence: localities 22 and 43, in January and No- 

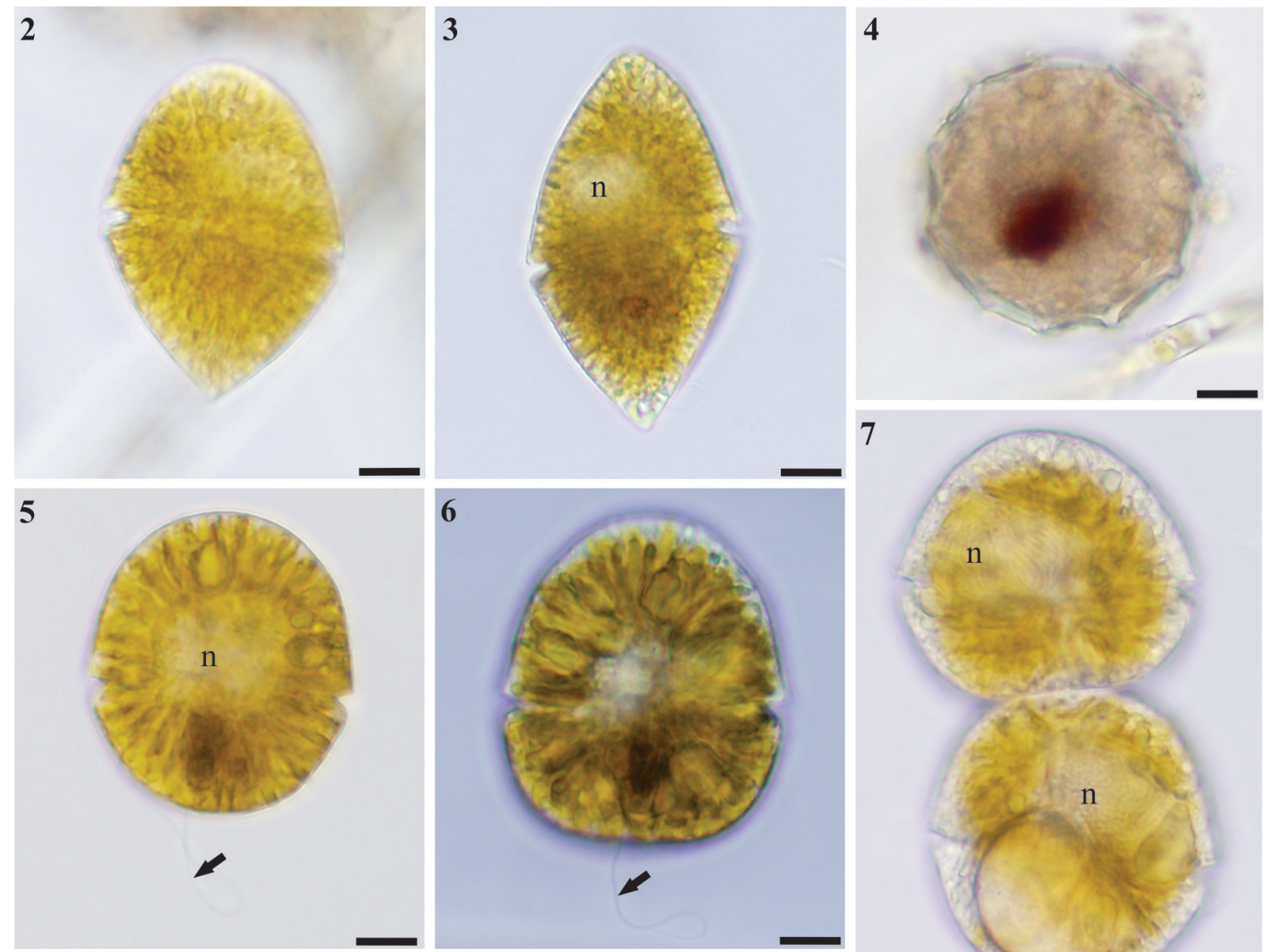

7
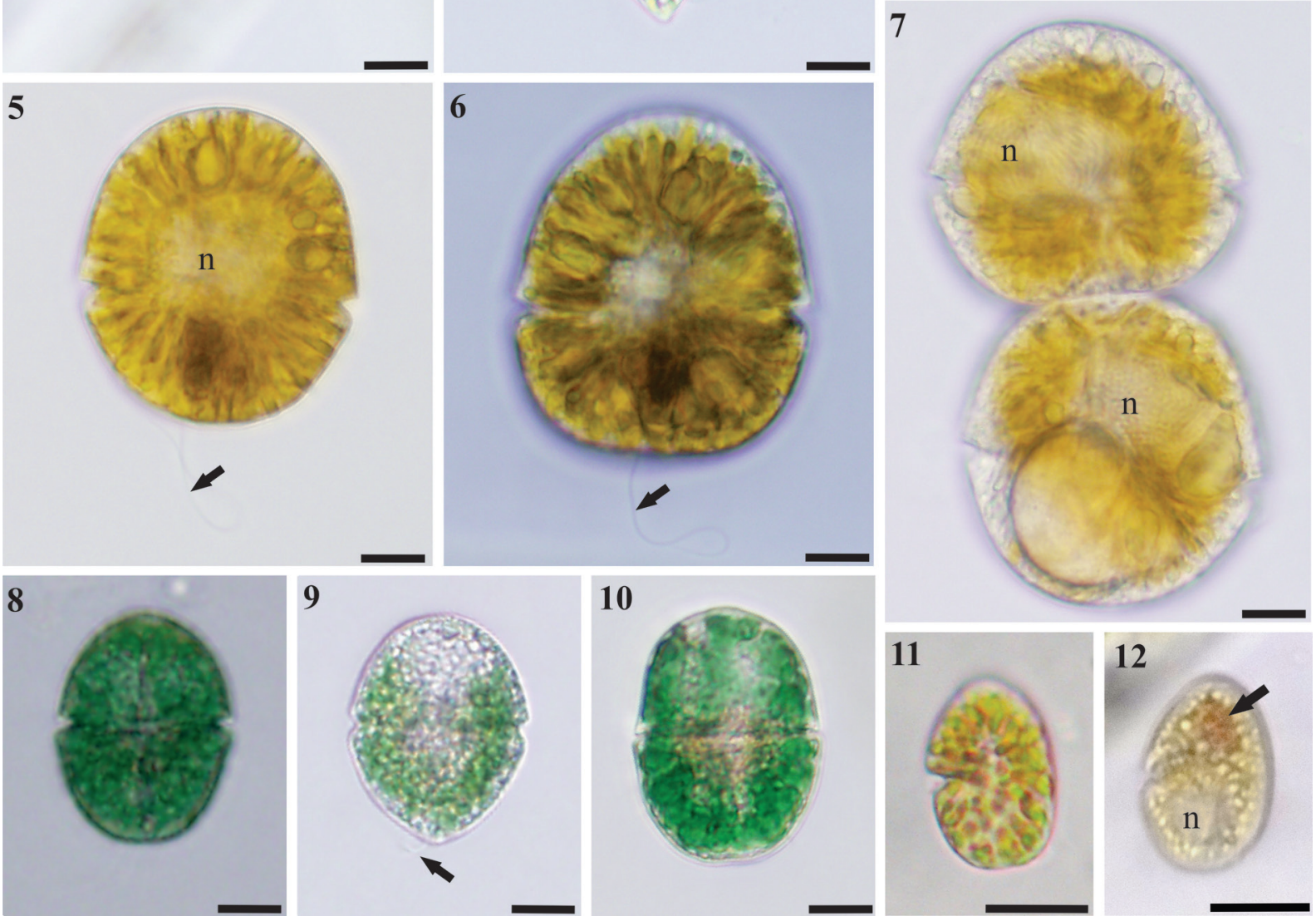

Figs 2-4. Gymnodinium fuscum, LM: (2) typical form, dorsal view; (3) specimen with a more conical epicone, ventral view; (4) resting cyst. Figs 5-7. Gymnodinium mirabile, LM: $(5,6)$ typical cells with longitudinal flagellum (arrow), ventral view; (7) cells in vegetative division, ventral view. Figs 8-10. Nusuttodinium aeruginosum in ventral view, LM: longitudinal flagellum in Fig. 9 (arrow). Figs 11, 12. Hemidinium nasutum, dorsal views, LM: (12) cell with red accumulation body in epicone (arrow). $\mathrm{n}=$ nucleus. Scale bars $10 \mu \mathrm{m}$.

vember 2012, respectively.

Comments: five different taxa of Hemidinium were reported in Brazilian waters (BICUdo \& Bicudo 1967; Bicudo \& Ventrice 1968; Bicudo \& Skvortzov 1970) but they were usually considered synonyms of $H$. nasutum or H. ochraceum Levander (PopovskÝ \& PfiesTER 1990). Hemidinium brasiliense BICUDO et SKVORTZov reportedly differs from $H$. nasutum by cell shape, length, and by having epicone larger than hypocone (Bicudo \& Skvortzov 1970). There are also two nontypical varieties described for that species: H. nasutum var. tatricum WoŁosZYŃsKA, which differs by larger cells and distinct thecal tabulation (PopovskÝ \& PFIESTER 1990) and N. nasutum var. lapeanum Bicudo et
Ventrice, with cells twice the size (60-70 $\mu \mathrm{m}$ long; 44-50 $\mu \mathrm{m}$ wide) than commonly found for H. nasutum (Bicudo \& Ventrice 1968). Forms with visible thecal plates have been shown to be part of the life cycle of Gloeodinium montanum G.A. KLEBS and may therefore be distantly related to $H$. nasutum (MoEsTRUP \& DAUGBJERG 2007). Our material closely fits the illustrations of typical $H$. nasutum.

Distribution in Brazil: recorded for Rio de Janeiro (CunHa 1916); H. nasutum var. tatricum and H. nasutum var. lapeanum were observed in States of São Paulo and Minas Gerais, respectively (BICUdo \& Bicudo 1967; Bicudo \& Ventrice 1968). This is the first record for southern Brazil. 


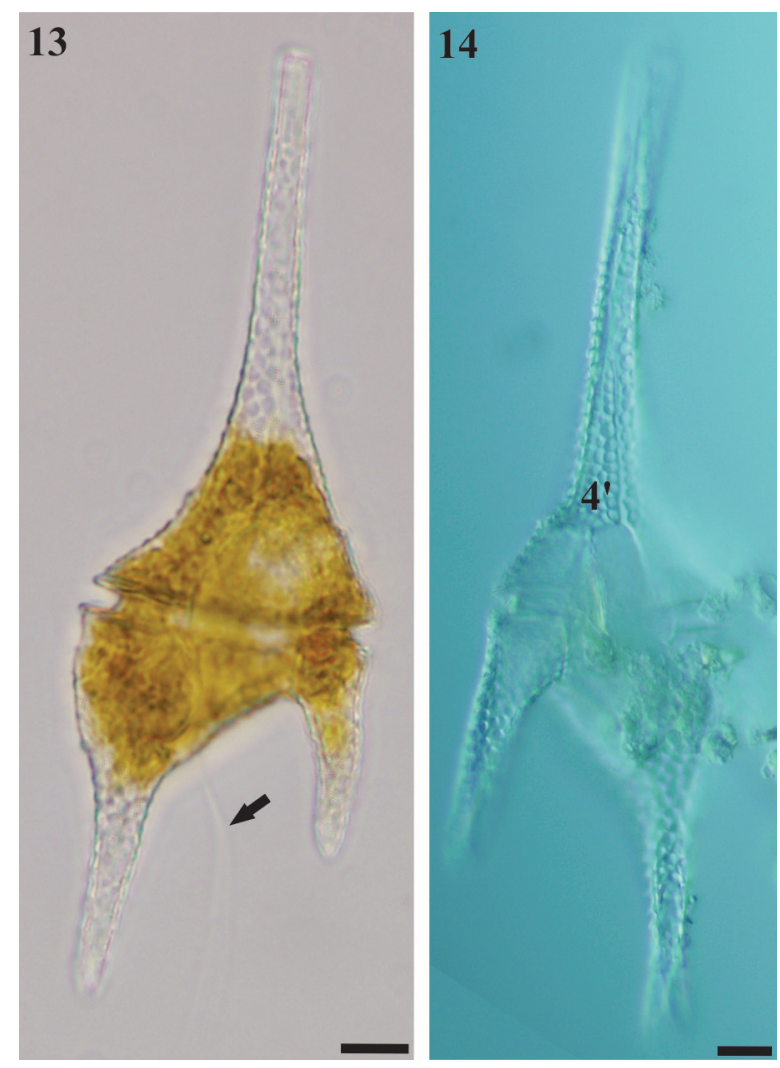

Figs 13-14. Ceratium furcoides, LM: (13) living cell in dorsal view with longitudinal flagellum (arrow); (14) empty theca in ventral view, showing 4' plate. Scale bars $10 \mu \mathrm{m}$.

\section{Thecate planktonic dinoflagellates}

Ceratium furcoides (Levander) Langhans (1925, p. 602) Figs 13-14

Basionym: Ceratium hirundinella var. furcoides LEVANDER (1894, p. 53, pl. II, fig. 24)

Large cells, dorsoventrally flattened, with ventral area strongly concave; cingulum median, not displaced; one conical apical horn, ending in an apical pore; two or three conical antapical horns, distinct in size; brownyellow plastids throughout the cell; oil and red bodies often present; thick theca, with reticulate ornamentation, plate formula: Po, 4', 5", 6c, ?s, 5', 2"',; plate 4' short, not reaching the apex. Length: 86-190 $\mu \mathrm{m}$; width: 26-57.8 $\mu \mathrm{m}$.

Occurrence: localities 1, 3, 4, 6, 10, 12, 20, 24, 26, 28, $29,34,35,38$. It was observed in all seasons.

Comments: shorter and rhomboidal cells found in this study could be interpreted as C. rhomvoides Hickel, a species closely related to C. furcoides (Hickel 1988). However, Brazilian populations studied here had a broad morphological variation. Moreover, preliminary molecular studies based on ITS and SSU rDNA sequences have indicated that Brazilian specimens are related to Portuguese populations clearly assigned to C. furcoides morphology (unpub. data). More studies are needed to clarify the boundary between these two species of Ceratium (PANDEIRADA et al. 2013).
Distribution in Brazil: C. furcoides is considered an invasive species in South America, recorded in southeastern (SAntos-Wisniewski et al. 2007; MatsumuRA-Tundisi et al. 2010), northeastern (OliveIRA et al. 2011), and southern Brazil (CAVAlCANTE et al. 2013; JATI et al. 2014).

Durinskia baltica (Levander) CARTy et E.R. Cox (1986, p. 200, figs 11-14) Figs 15-21

Basionym: Glenodinium balticum LeVANDER (1894, p. 52; figures in LEVANDER 1892, p. 407, figs 1-4)

Round cells, spherical to slightly dorsoventrally flattened; epitheca larger than hypotheca, cingulum slightly descending; narrow and shallow sulcus, not reaching the antapex; apical pore not projected in the apex; numerous discoid golden brown plastids; conspicuous eyespot, bright red, with an anterior comma-like projection (Fig. 16); thin theca, smooth, with scattered pores, sometimes forming rows; plate formula: Po, X, 4', 2a, 6", 5c, ?s, 5"', 2"',. Length: 23.7-36.7 $\mu \mathrm{m}$; width: $21-35 \mu \mathrm{m}$.

Occurrence: localities $21,25,35,40,42$. It was observed between September and January (spring-summer).

Comments: Durinskia baltica, the most usual name for this species complex, was originally described from brackish water (type locality: Gulf of Finland, near Helsinki, Levander 1892). Thenceforth, it has been cited in marine (HallegraefF et al. 2010; HopPENRATH et al. 2014), estuarine (Couté et al. 2012), and freshwater environments (PANDEIRADA et al. 2013; ZHANG et al. 2011). The morphometry of individuals illustrated in different habitats overlaps. STEIN (1883) established the species Glenodinium oculatum F. STEIN, depicting no plates on the cell cover. However, the overall cell shape, the presence of a theca and the positions of nucleus and eyespot, as depicted by STEIN (1883), fit the current concept of Durinskia and were the basis for the species transfer (HANSEN \& FLAIM 2007). However, the difference between individuals of Durinskia oculata (F. Stein) Gert Hansen et Flaim and $D$. baltica, as shown by Hansen \& Flaim (2007), namely more dorsoventrally flattened cells in $D$. baltica, is not easily ascertained as both flat and globular cells can be seen in a population (e.g. CARTY \& COX 1986; Zhang et al. 2011; Couté et al. 2012). Moreover, it is unclear whether Stein's specimens were distinctly globular (STEIN 1883). The freshwater species Peridinium dybowskii was described by WoŁoszYŃsKA (1916) with the same plate tabulation of $D$. baltica. In the same work, WoŁoszYŃSKA (1916, p. 273, footnote) stated that the species was identical to that illustrated by LEVANDER (1892, as Glenodinium cinctum EHRENBERG). WoŁoszyŃSKA was apparently unaware that LEVANDER published for that species the name $G$. balticum (LEVANDER 1894). The plate ornamentation of $P$. dybowskii, with pores arranged in parallel lines, was used by some authors as a distinctive feature between both species (Hansen \& Flaim 2007). CARTY 

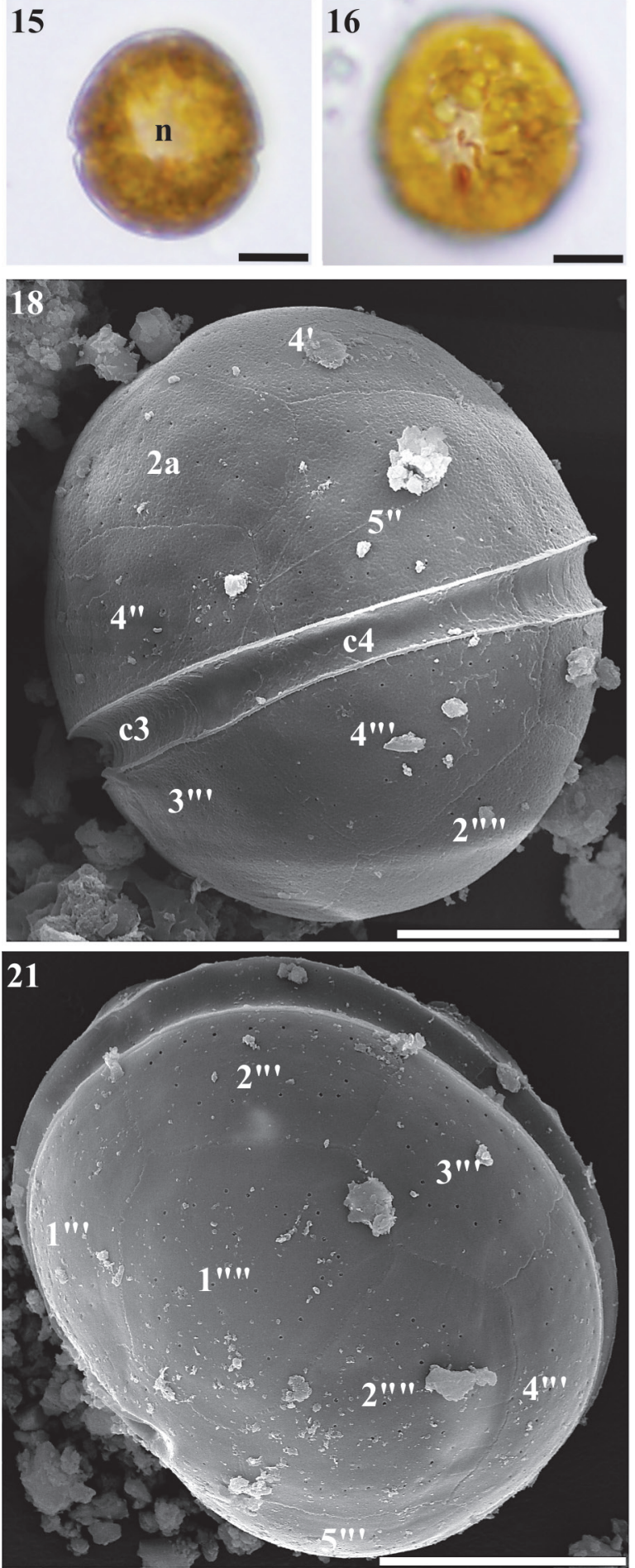
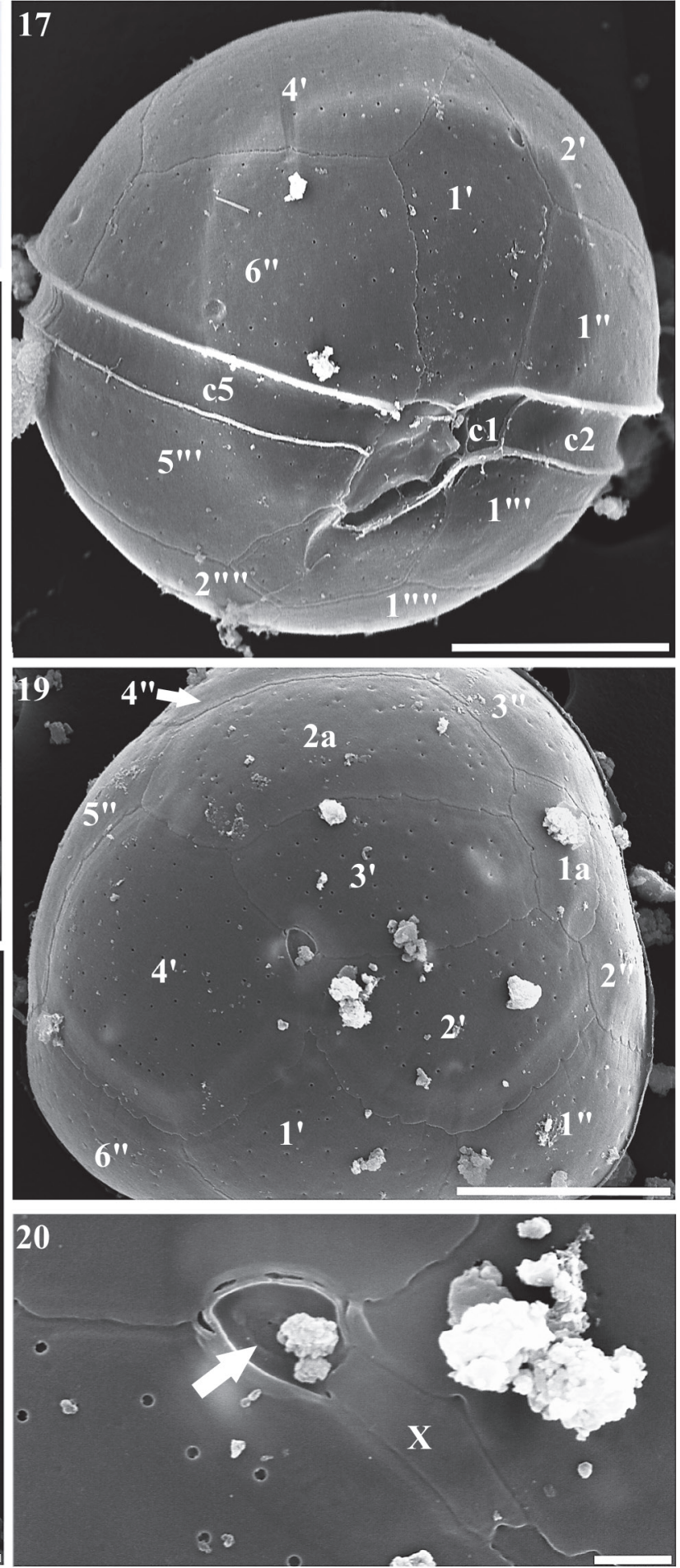

Figs 15-21. Durinskia baltica: $(15,16)$ LM, showing nucleus (n) and eyespot with anterior comma-like projection; (17-21) SEM, (17) ventral view, (18) dorsal view, (19) apical view, (20) detail of apical pore (arrow) and canal plate (X), (21) antapical view. Scale bars $10 \mu \mathrm{m}$ (Figs 15-19, 21), $1 \mu \mathrm{m}$ (Fig. 20).

(2014) created the combination Durinskia dybowskii (WoŁoszYŃSKA) CARTY, and proposed to refer all freshwater individuals to this species, while including marine and brackish populations in D. baltica. Apart from morphological limitations, ecological aspects need to be considered with caution, since the taxonomic markers traditionally used for differentiation of these spe- cies do not agree with habitat information. Considering them as separated entities requires modern analyses of different populations and accurate taxonomic studies of the original material. For now, we prefer to maintain the name Durinskia baltica, since it is the most widely used name and has an unambiguous nomenclatural type associated. 

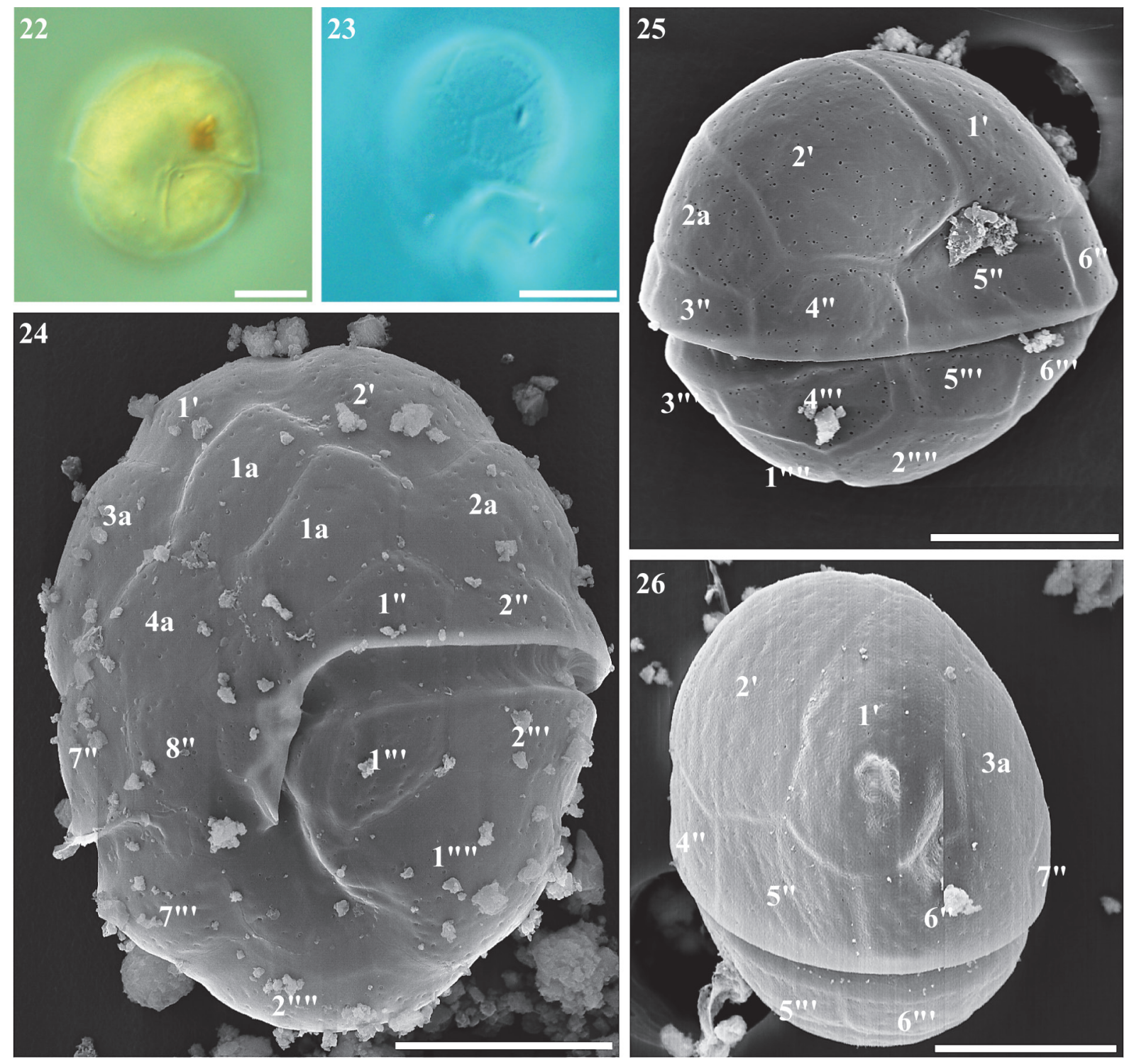

Figs. 22-26. Glenodiniospsis uliginosa: (22) ventral view of fixed cell, LM; (23) empty theca in LM, showing delicate plates; (24) ventral view, SEM; (25) dorsal view, SEM; (26) apical view of dorsal epitheca. Scale bars $10 \mu \mathrm{m}$.
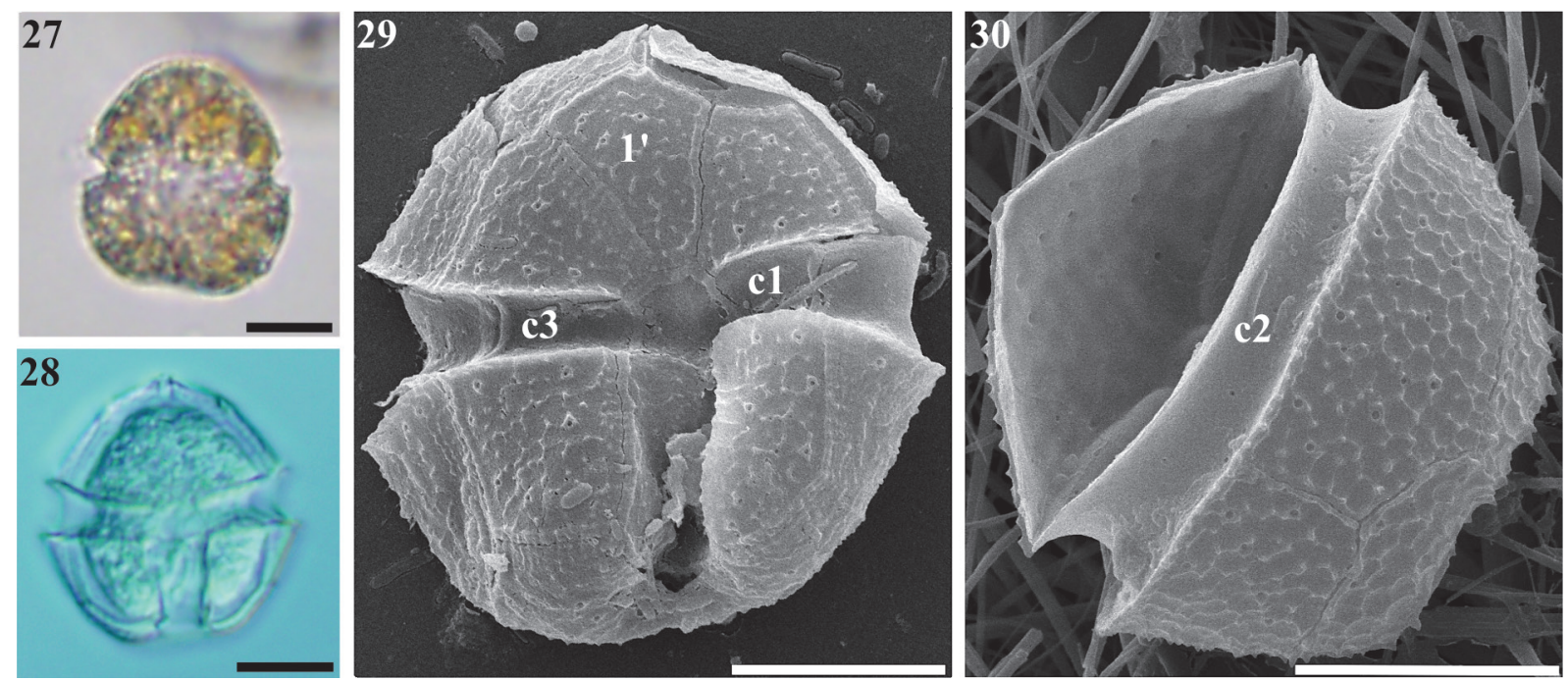

Figs. 27-30. Glochidinium penardiforme: (27) living cell, LM; (28) fixed cell in ventral view, LM; (29) ventral view, SEM; (30) dorsal view, SEM, showing ecdysis opening formed by detachment of plates 1a (or 3' for some authors) 3" and 4". Scale bars $10 \mu \mathrm{m}$. 
Distribution in Brazil: all three names have been reported in Brazilian environments. D. dybowskii was recorded in São Paulo (KLeEReKoper 1939), D. oculata was reported in Rio Grande do Sul (FrANCESCHINI 1992; GARCIA-BAPTISTA 1993), and D. baltica in Rio de Janeiro (Domingos \& Menezes 1998) and Rio Grande do Sul (CARDoso \& ToRgan 2007; CARdoso et al. 2010). It is necessary to verify the conspecificity of those populations.

Glenodiniopsis uliginosa (A.J. SCHILling) WoloszyńsKa in Lindemann (1928, p. 82) Figs 22-26 Basionym: Glenodinium uliginosum A.J. Schilling (1891, p. 283, pl. X, fig. 16)

Oval cells, dorsoventrally flattened; epitheca larger than hypotheca, cingulum slightly descending; narrow and shallow sulcus, not reaching the antapex; apical pore absent; brown-gold plastids; accumulation bodies often present; eyespot absent; thin theca, smooth, with scattered pores; two large apical plates along the apex; plate formula: 2', 4(or 5)a, 8", ?c, ?s, 7"', 2"'. Length: 26.3-36.8 $\mu \mathrm{m}$; width: 18.9-30.5 $\mu \mathrm{m}$.

Occurrence: locality 35 . It was observed in September and December 2014.

Comments: plate tabulation is similar to that found in Hansen \& Flaim (2007), with la divided in two plates (Fig. 24). This taxon was named Glenodiniopsis steinii WoŁoszyńska in several floras (Popovský \& Pfiester 1990, CARTY 2014). However, this name is a later synonym of Glenodinium uliginosum (SCHILLER 1937, HuBer-Pestalozzi 1950, Hansen \& Flaim 2007).

Distribution in Brazil: Odebrecht et al. (2015) referred to two previous records of Glenodiniopsis WoŁoszyńsKa to Rio de Janeiro and Mato Grosso, but they are linked to a species of Sphaerodinium WoŁoszyńska instead (Prowazek 1910, Menezes \& FERNANDES 1990). This is therefore the first confirmed record of this species for Brazil.

Glochidinium penardiforme (ER. LINDEMANN) Boltovskoy (1999, p. 99, figs 2-7, 14-23) Figs 27-30 Basionym: Peridinium penardiforme ER. LindEMANN in SCHRÖDER (1919, p. 654, fig. 1)

Oval or pentagonal cells in ventral view, dorsoventrally flattened; epitheca variable, equal, larger or smaller than hypotheca; hypotheca bilobate in antapex; cingulum circular, excavated; narrow sulcus, reaching the antapex; apical pore slightly projected in the epicone; cells without plastids or with brown-gold plastid-like structures; accumulation bodies often present; eyespot absent; theca with irregular nodules and scattered pores; plate formula: Po, X, 4' (or 3'+1a), 6', 3c, ?s, 5"', 2"'. Length: 18.3-34 $\mu \mathrm{m}$; width: 14.7-28 $\mu \mathrm{m}$.

Occurrence: localities 1, 3, 5, 6, 7, 8, 9, 10, 12, 14, $16,17,18,29$. It was observed at various periods of the year.

Comments: this species has been found with or without plastids here and in several other works (HUBERPestalozzi 1950; Popovský \& Pfiester 1990; Boltovs-
KOY 1999; PANDEIRADA ET AL. 2013). This feature is unusual and intriguing and the nutritional strategy of this species needs to be elucidated.

Distribution in Brazil: Amazonas (UHERKovich 1976; Uherkovich \& Rai 1979), Rio de Janeiro (Menezes \& TEIXEIRA-JúnIOR 2001), and Rio Grande do Sul (CARDoso et al. 2010).

\section{Parvodinium CARTy (2008, p. 106)}

This genus includes a group of small peridinioids with plate tabulation: Po, X, 4', 2a, 7", 6c, 4s, 5'", 2"', (CARTY 2008). The wide morphological variability performed in this group resulted in the description of many species over time (CARTY 2008). In contrast, some authors considered such variations as phenotypic plasticity within the few species, and then synonymized the majority of those names (Popovský \& PFIESTER 1990). Preliminary molecular studies indicated that there are distinct species within this complex (Y. TAKANO, unpubl. data, see HANSEN \& Flaim 2007), but the phylogenetic relationships among Parvodinium spp. have not been resolved yet. In this study, to highlight morphological variation, we decided to consider morphospecies strictly based on the original publication concepts, as follows:

Parvodinium africanum (Lemmermann) CARTy (2008, p. 106) var. africanum Figs 31-33

Basionym: Peridinium africanum Lemmermann in West (1907, p. 188, pl. 9, fig. 1 a-e)

Cells in ventral view pentagonal, dorsoventrally flattened; angular outline, formed by elevations in the plates junctions; epitheca conical, larger than hypotheca; hypotheca trapezoidal, with many spines of variable length; cingulum circular, excavated; wide sulcus, slightly extending onto the epitheca and reaching the antapex; apical pore protruded; large intercalary plates. Length: $21.9-40 \mu \mathrm{m}$; width: 18.8-36 $\mu \mathrm{m}$.

Occurrence: localities 2, 5, 6, 8, 9, 14, 17, 18, 35. It occurred predominantly in summer samples.

Comments: four infraspecific taxa have been formally proposed for $P$. africanum (LEFÈVRE 1932), but were considered as synonyms in some floras (Popovský \& PfIESTER 1990). The typical variety of $P$. africanum has shorter pentagonal cells, with shorter spines and its sulcus slightly extending onto the epitheca (WEST 1907).

Distribution in Brazil: Parvodinium africanum has been recorded in Mato Grosso (Menezes \& Fernandes 1990), Amazonas (MenEzes et al. 1995), Minas Gerais (Borics et al. 2005), and Rio Grande do Sul (CARDOSO et al. 2010) without identification at infraspecific level. Records of Peridinium quadridens F. STEIN in São Paulo (SANT'AnNa et al.1988) and Peridinium umbonatum F. Stein in Espírito Santo (Delazari-Barroso et al. 2007) may both correspond to $P$. africanum, judging from the illustrations given. 
Parvodinium africanum var. javanicum (Woloszyńska) Cavalcante, Craveiro, Calado et Cardoso comb. nov. Figs 34-38

Basionym: Peridinium marchicum var. javanicum WoŁoszYŃsKA (1912, Bull. Int. Acad. Sci. Cracovie B: Sci. Nat., p. 703, text-fig. 25)

Cells pentagonal in ventral view, dorsoventrally flattened; angular outline, formed by elevations in the plates junctions; epitheca conical, larger than hypotheca; hypotheca trapezoidal, with many long spines; cingulum circular, excavated; wide sulcus, extending onto the epitheca and reaching the antapex; apical pore protruded; small intercalary plates. Length: 30.8-36.6 $\mu \mathrm{m}$; width: $26.2-32.3 \mu \mathrm{m}$.

Occurrence: only in locality 7 . This population was present during fall 2012.

Comments: this population had large cells, with numerous long spines, the sulcus broadly extended into epitheca and had reduced intercalary plates. These features correspond to the circumscription of Peridinium marchicum var. javanicum (WoŁosZYŃsKA 1912). This taxon was never transferred to Parvodinium, and the new combination is proposed here.

Distribution in Brazil: first record of this variety in Brazilian freshwaters, but see comments on the distribution of $P$. africanum var. africanum.

\section{Parvodinium centenniale (Playfair) CARTy (2008, p. 106) Figs 39-42}

Basionym: Peridinium umbonatum var. centenniale PLAYFaIR (1920, p. 806, text-fig. 14)

Elliptical cells; epitheca widely round, markedly larger than hypotheca; hypotheca round, no spines; cingulum slightly descending; round shallow sulcus, obliquely extending onto the epitheca and not reaching the an-
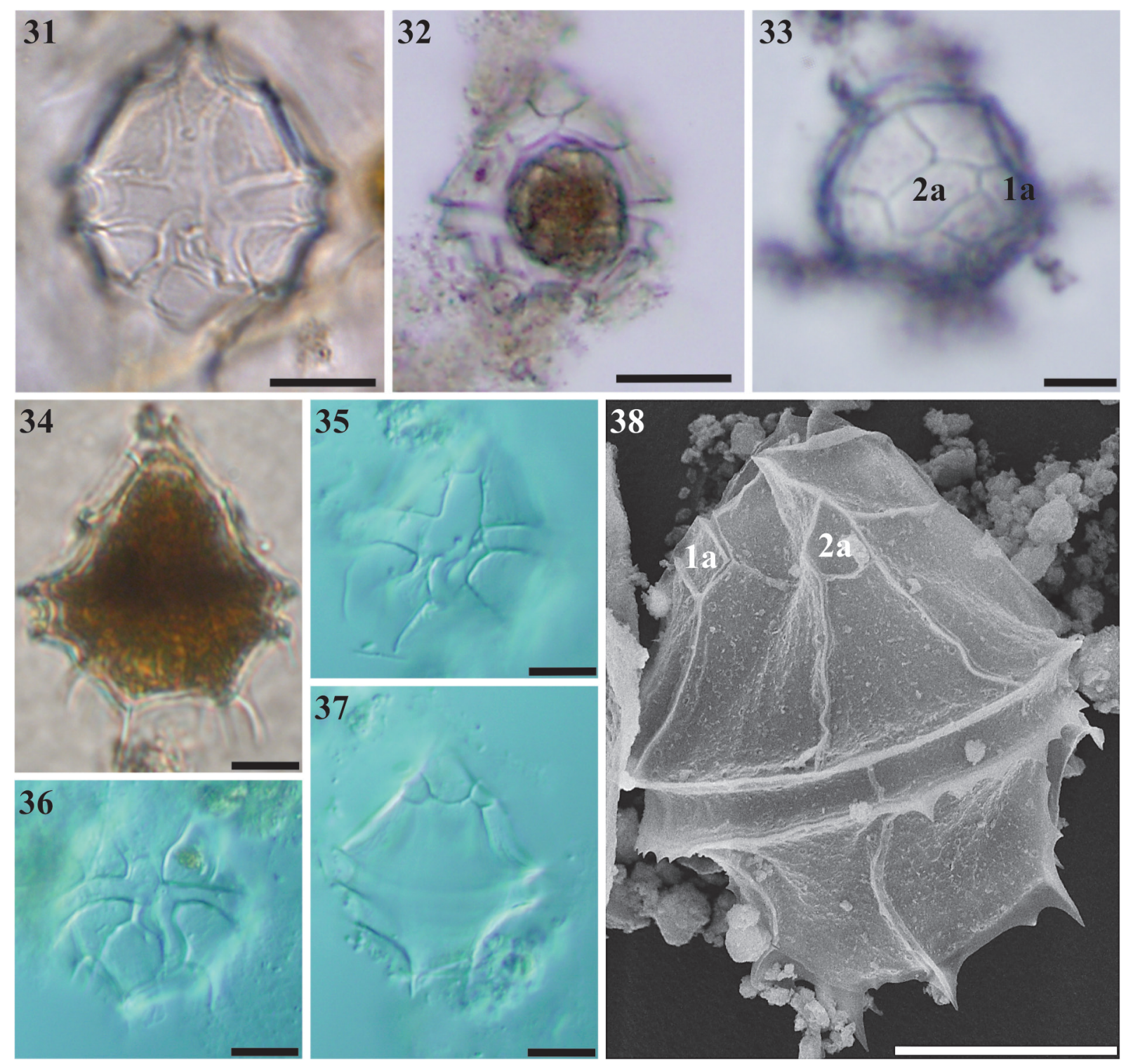

Figs. 31-33. Parvodinium africanum var. africanum, LM: (31) ventral view; (32) dorsal view; (33) apical view; (34-38) P. africanum var. javanicum comb. nov, (34) fixed cell, LM, (35) ventral view, LM, (36) ventral view of the hypotheca, LM, (37) dorsal view, LM, (38) dorsal view, SEM. Scale bars $10 \mu \mathrm{m}$. 


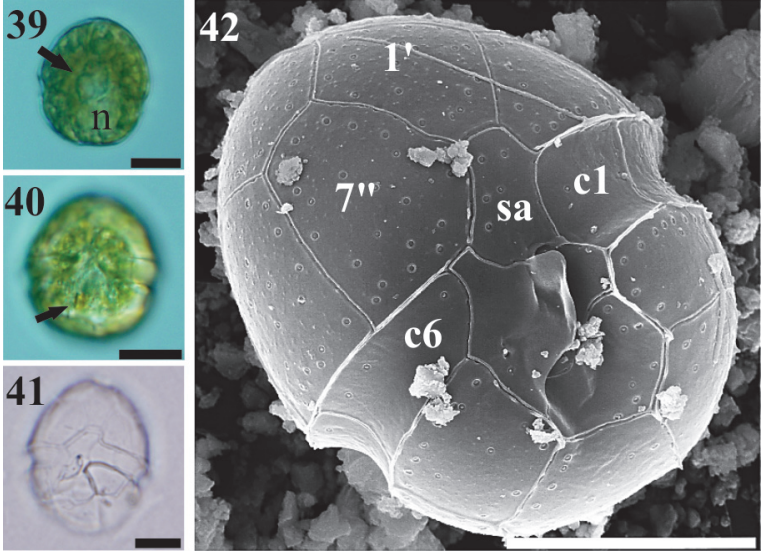

Figs 39-42. Parvodinium centennial: (39) living cell, LM, showing nucleus (n) in the hypocone and probably a pyrenoid in the epicone (arrow); (40) living cell, LM, showing eyespot (arrow); (41) empty theca in ventral view, LM; (42) cell in ventral view, SEM. Scale bars $10 \mu \mathrm{m}$.

tapex; apical pore not projected, slightly shifted to the left; brown-golden plastids; nucleus located in hypocone, and a large inclusion body (maybe a pyrenoid) in the epicone; diminute eyespot sometimes observed; plates smooth, with scattered pores. Length: 20-33.6 $\mu \mathrm{m}$; width: 13.3-24.2 $\mu \mathrm{m}$.

Occurrence: only in locality 21 . It was present at various periods of the year.

Comments: our specimens are nearly identical to those showed in Hansen \& Flaim (2007). Several morphologically similar taxa into this group were described by Playfair (1920). The phylogenetic relationship among them needs to be clarified.

Distribution in Brazil: there are records of $P$. centenniale in States of São Paulo (KLEEREKOPER 1939) and Minas Gerais (Borics et al. 2005), both lacking illustrations, which makes impossible the comparison with our taxon. The specimen identified and illustrated as "Peridinium centenniale forma ?" in UHERKOVICH (1981) for Amazonas does not correspond to P. centenniale stricto sensu.

\section{Parvodinium umbonatum/inconspicuum species complex}

\section{Morphospecies 1 Figs 43-50}

Elliptical cells, slightly flat in the ventral side; epitheca conical, markedly larger than hypotheca; hypotheca angular with spines; cingulum slightly descending; wide sulcus, extending into the epitheca and reaching the antapex; apical pore large and projected; browngolden plastids; plates smooth with scattered pores. Length: 14-23.3 $\mu \mathrm{m}$; width: 10-20 $\mu \mathrm{m}$.

Occurrence: localities 2, 3, 6, 7, 14, 16, 19, 35, 37, 41 . It was observed in all seasons.

Comments: distinction between $P$. inconspicuum (Lemmermann) CARTy and P. umbonatum (F. Stein) CARTY is quite inaccurate (ElBrÄCHTER \& MEYer 2001;
HANSEn \& Flaim 2007; TARdio et al. 2009; Pandeirada et al. 2013). The original illustration of $P$. umbonatum showed a medium-size cell (at least $25 \mu \mathrm{m}$ ) with a long and narrow epitheca, that was about $2 / 3$ of the cell length. A precise tabulation was given; however, species of this complex have broad intraspecific variation in plate pattern, especially on intercalary plates (ELBRÄCHTER \& MEYER 2001). Additionally, the illustrations presented by STEIN (1883, pl. XII, figs 1-8) have no evidence of antapical spines. Parvodinium umbonatum as interpreted by subsequent authors is usually quite different from the strict original concept. The original description of $P$. inconspicuum, without illustrations, is even more subjective (LEMMERMANN 1900, p. 350). Original illustrations were provided in LEMMERMANN (1910, p. 663, figs 28 and 29). These works mentioned small pentagonal cells, 15-18 $\mu \mathrm{m}$ long, with short spines and almost median cingulum (LEMMERMANN 1900, 1910). Such features are widely used by authors to distinguish these taxa, but they are difficult to apply due to the morphological variability found in the populations. In this study, cells were smaller than $25 \mu \mathrm{m}$ and spiny, and could be easily assigned to $P$. inconspicuum. However, cell shape and cingulum position are more similar to P. umbonatum. HANSEN \& Flaim (2007) showed typical cells that better fit in $P$. inconspicuum sensu stricto, which are clearly distinct from our specimens. Because of the uncertainties about the identification of this taxon, we prefer designate it as $P$. umbonatum/inconspicum species complex, highlighting the need of a detailed review on this taxonomic group.

Distribution in Brazil: this taxon has broad distribution in Brazilian freshwaters, recorded as P. umbonatum and/or P. inconspicuum in Pará, Amazonas, Rondônia, Mato Grosso, Goiás, Distrito Federal, Minas Gerais, Rio de Janeiro, São Paulo, and Rio Grande do Sul (Odebrecht et al. 2015). The record of P. umbonatum in the State of Espírito Santo based on illustrations provided by Delazari-Barroso et al. (2007) corresponds to $P$. africanum. Morphological variation into these records can be hidden as these species were commonly considered as synonyms.

\section{Morphospecies 2 Figs 51-55}

Cells pentagonal in ventral view, dorsoventrally flattened; epitheca conical, larger than hypotheca; hypotheca angular, no spines; cingulum slightly descending; wide sulcus, extending onto the epitheca and reaching the antapex; apical pore not or slightly projected; brown-golden plastids; plates densely ornated with diminute warts and scattered pores. Length: 24-29.7 $\mu \mathrm{m}$; width: 19.4-24.6 $\mu \mathrm{m}$.

Occurrence: only in locality 31 . It was found in high numbers in an acidic lake in December 2011.

Comments: this atypical population showed larger cells, angular hypotheca without spines and almost median cingulum. Only P. umbonatum was found with 

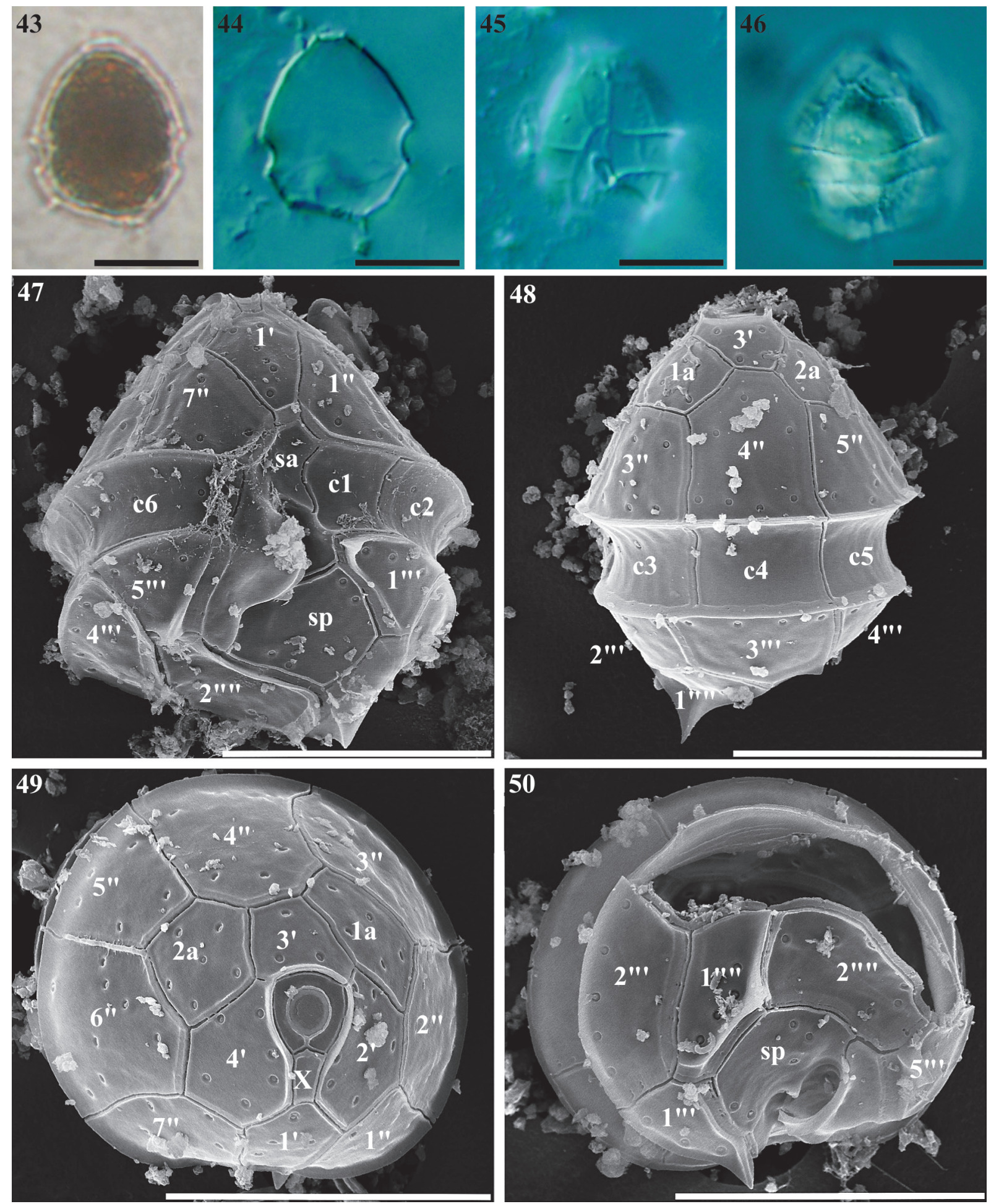

Figs 43-50. Parvodinium umbonatum/inconspicuum morphospecies 1: (43) fixed cell in ventral view, LM; (44) empty theca in ventral view, LM; (45) ventral tabulation, LM; (46) dorsal tabulation of epitheca, LM; (47) ventral view, SEM; (48) dorsal view, SEM; (49) apical view, SEM; (50) antapical view, SEM. Scale bars $10 \mu \mathrm{m}$.

those dimensions in the literature, however the cell shape does not correspond to the original concept of this species.

Distribution in Brazil: we cannot find any record of Parvodinium spp. in literature with similar features.
Peridiniopsis cunningtonii Lemmermann in West (1907, p. 189, pl. 9, fig. 2 a-e) Figs 56-59

Piriform cells, dorsoventrally flattened; epitheca conical, larger than hypotheca; hypotheca round, with 4-6 spines, one in each posterior plate; cingulum slightly descending; wide sulcus, extending onto the epitheca and reaching the antapex; apical pore projected; 




Figs 51-55. Parvodinium umbonatum/inconspicuum morphospecies 2: (51) fixed cell in ventral view, LM; (52) ventral view, SEM; (53) dorsal view, SEM; (54) detail of the apical pore complex, SEM; (55) left lateral view. Scale bars $10 \mu \mathrm{m}$ (Figs 51-53, 55), $1 \mu \mathrm{m}$ (Fig. 54).
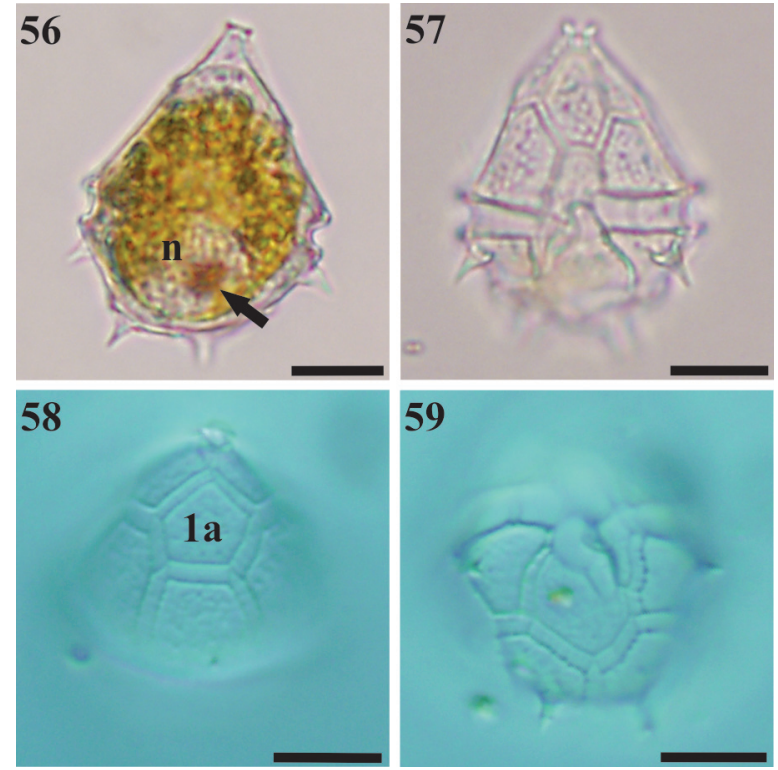

59

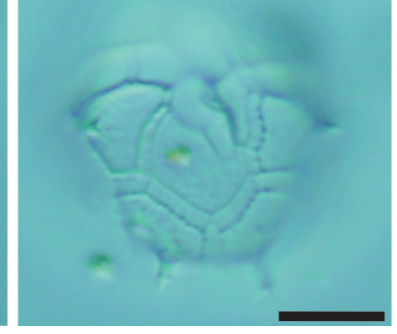

Figs 56-59. Peridiniopsis cunningtonii, LM: (56) living cell in ventral view, showing nucleus (n) and eyespot (arrow); (57) empty theca in ventral view; (58) epithecal tabulation in dorsal view; (59) ventral view of hypotheca. Scale bars $10 \mu \mathrm{m}$. brown-golden plastids; nucleus located in hypocone; eyespot present; plates with small warts; plate formula:

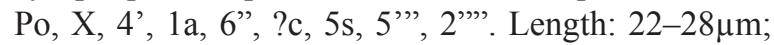
width: $15-25 \mu \mathrm{m}$.

Occurrence: localities 17, 18, 30, 32, 33, 36. It was observed at various periods of the year.

Distribution in Brazil: São Paulo (SANT'AnNA et al. 1989), Mato Grosso (Menezes \& Fernandes 1990), and Minas Gerais (Borics et al. 2005). Previous records of P. cunningtonii in Amazonian region (UhERKOVICH 1976, 1981; Uherkovich \& RAI 1979) correspond to Peridiniopsis amazonica instead (Meyer et al. 1997). This is the first record for southern Brazil.

Peridiniopsis elpatiewskyi (Ostenfeld) Bourrelly (1968, p. 9) Figs 60-68

Basionym: Peridinium umbonatum var. elpatiewskyi Ostenfeld (1907, p. 391, pl. 9, figs 9-12; typus conservandus, see Meyer \& ELBRÄCHTER 1996)

Cells pentagonal in ventral view; epitheca conical, larger than hypotheca; hypotheca angular, with numerous spines along sutures of posterior plates; cingulum almost circular; wide sulcus, extending into the epi- 

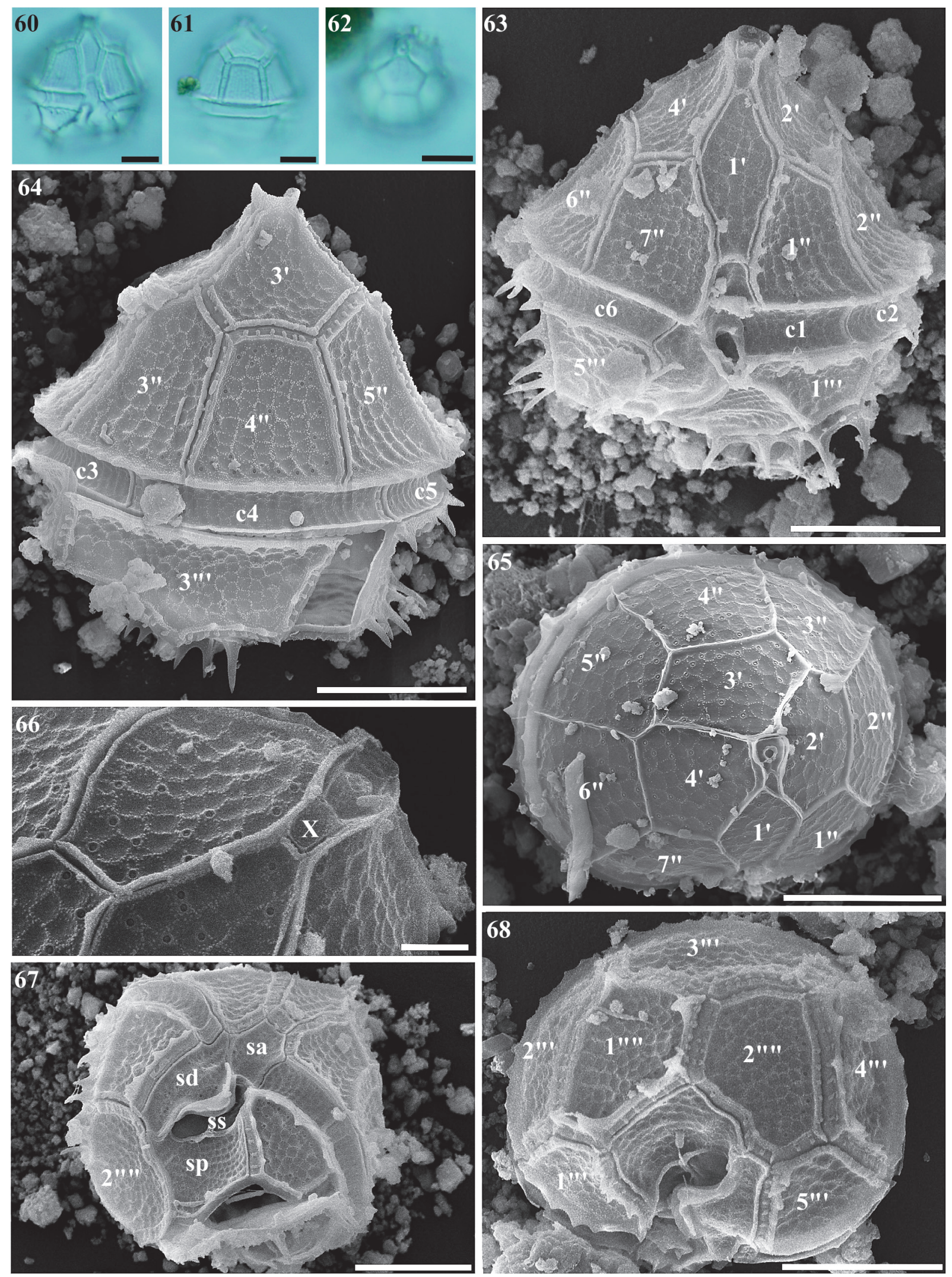

Figs 60-68. Peridiniopsis elpatiewskyi: (60) empty theca in ventral view, LM; $(61,62)$ epitheca in dorsal and almost apical view, LM; (63) ventral view, SEM; (64) dorsal view, SEM; (65) apical view, SEM; (66) detail of apical pore complex, SEM; (67) hypotheca in ventral view, showing sulcal plates, SEM; (68) antapical view. Scale bars $10 \mu \mathrm{m}$ (Figs 61-65, 67, 68), $2 \mu \mathrm{m}$ (Fig. 66). 

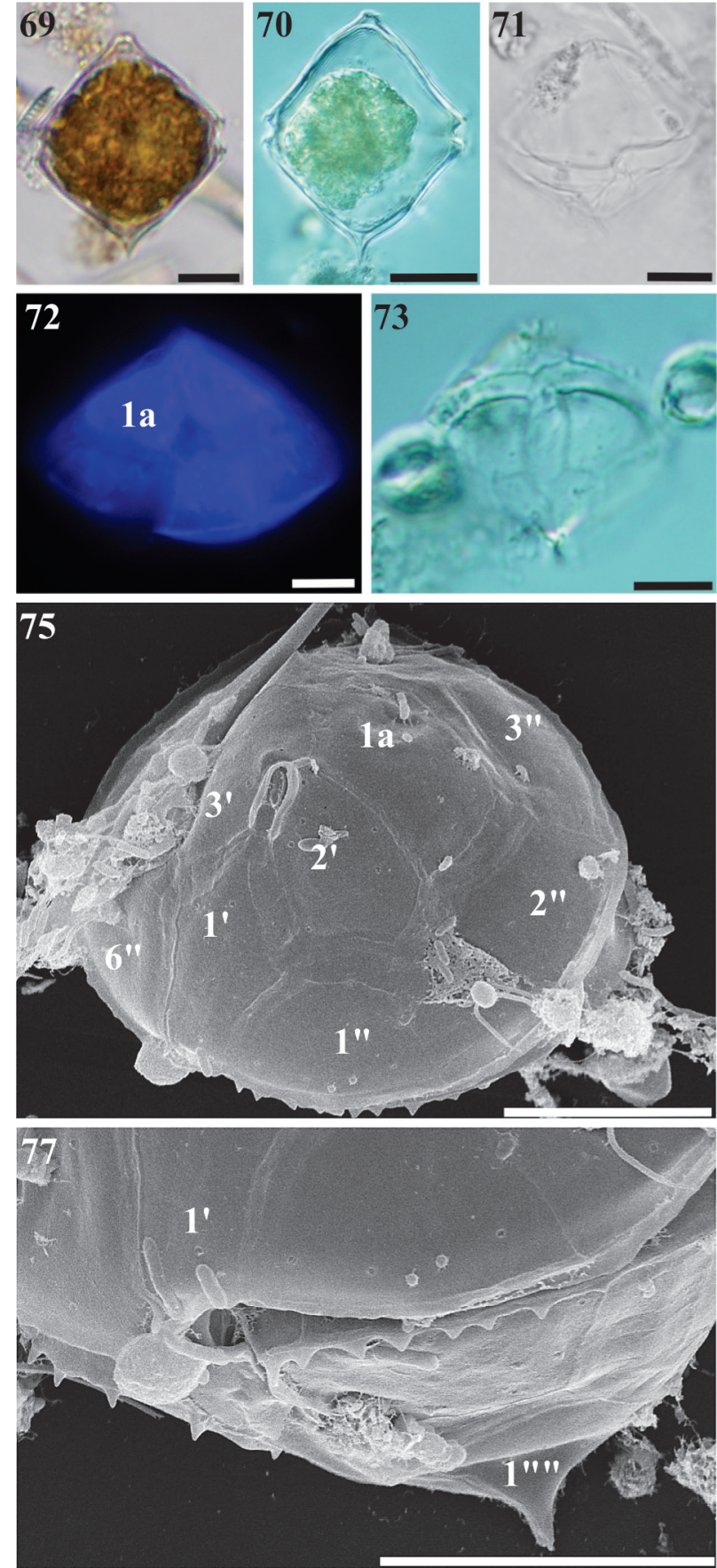
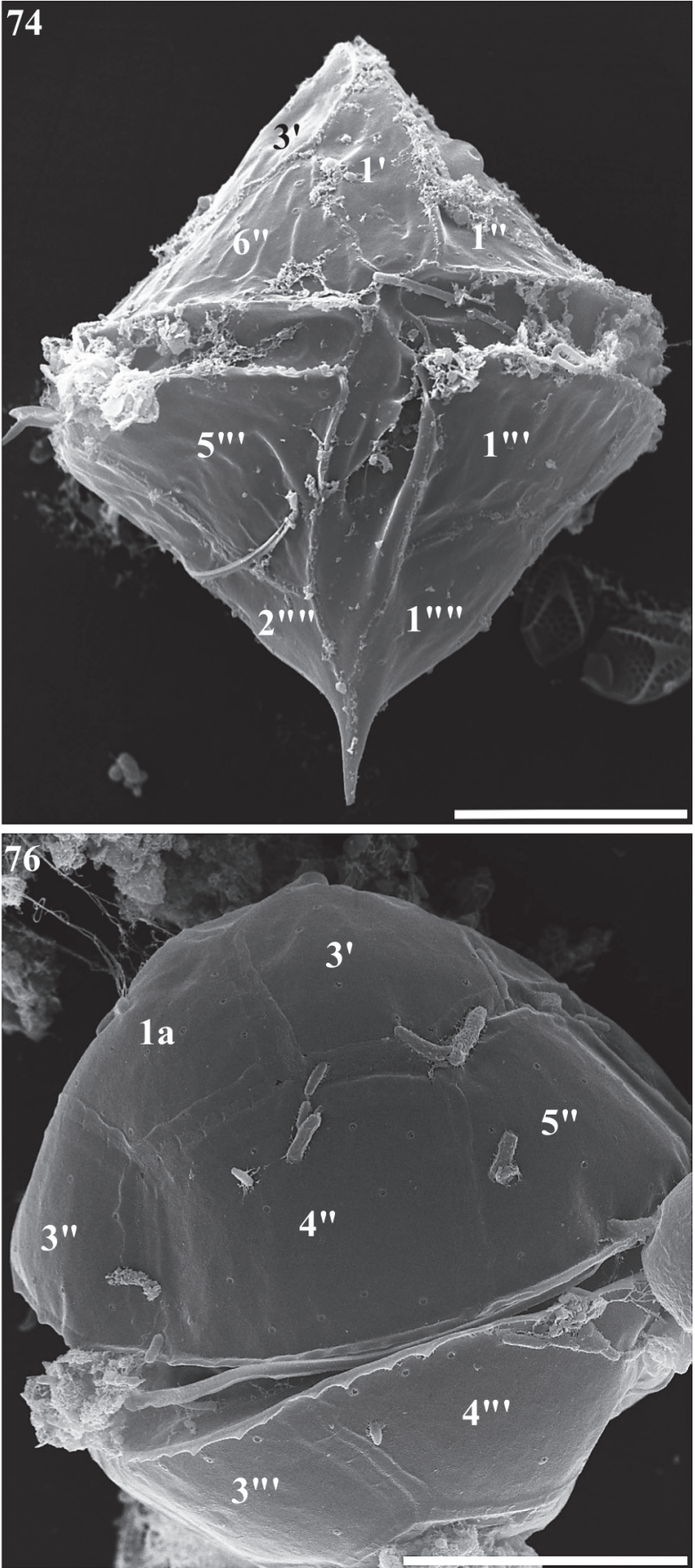

Figs 69-77. Peridiniopsis cf. kevei: (69) living cell, LM; (70) fixed cell, LM; (71) empty epitheca in ventral view, LM; (72) epitheca in dorsal view, showing plate 1a, epifluorescence LM; (73) hypotheca in ventral view, showing narrow sulcus and antapical plates, LM; (74) ventral view, SEM; (75) apical view, SEM; (76) dorso-lateral view, SEM; (77) detail of ventral cingular area, showing serrated lists. Scale bars $10 \mu \mathrm{m}$.

theca and reaching the antapex; apical pore protruded; brown-golden plastids; plates reticulated, with small warts and scattered pores; plate formula: Po, X, 4', 7', 6c, 4s, 5'", 2"'. Length: 20-36 $\mu \mathrm{m}$; width: 16-27 $\mu \mathrm{m}$. Occurrence: localities 30, 32, 33, 35, 36, 42. It was observed at various periods of the year, especially in quarry lakes.

Comments: Peridinium pygmaeum Lindemann was proposed as being a $P$. elpatiewskyi "in miniature", $22 \mu \mathrm{m}$ long (LindEMANN 1918), while P. elpatiewskyi is $30-45 \mu \mathrm{m}$ long (LEFÈVRE 1932). The dimensions of the population found in this study include the measurements given for both species. Some authors have considered these species as conspecific (PoPOVsKÝ \& PFIESTER 1990; AsCENCIO et al. 2015). Differences in size are common among different populations of the same dinoflagellate species. Moreover, we did not find morphological evidence for discrimination between the specimens described in this study and larger $P$. elpatiewskyi cells from literature (compare Figs 60-68 with those illustrated in SENZAKI \& HoRIGUCHI 1994; HANSEN \& Flaim 2007; Carty 2014 or Ascencio et al. 2015). 

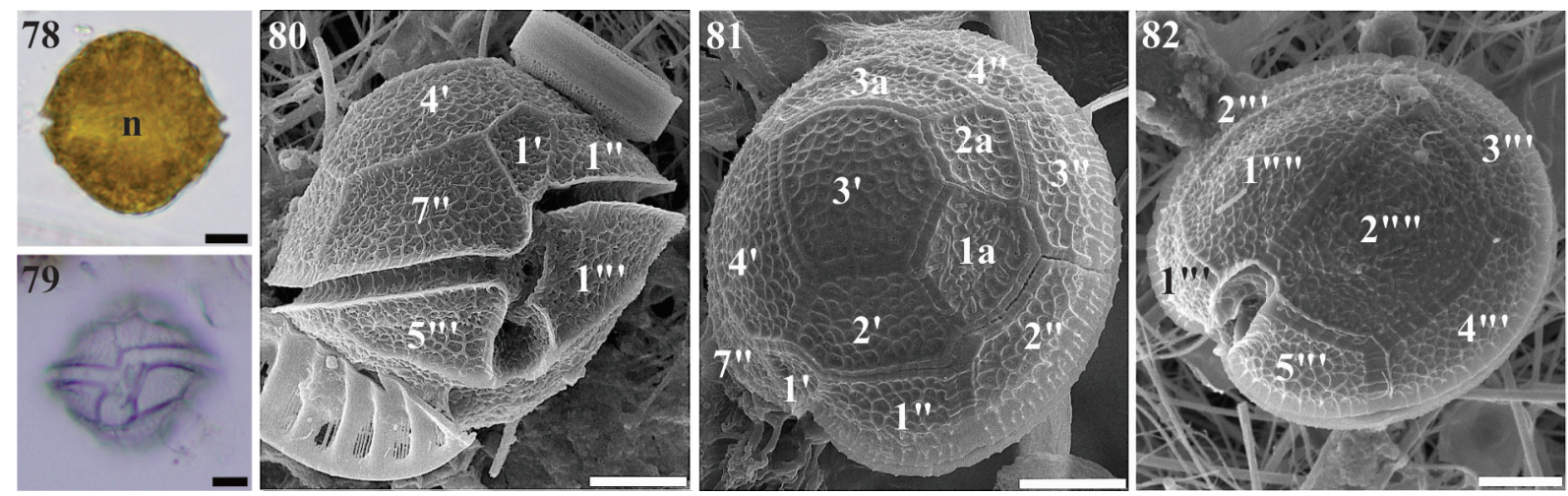

Figs 78-82. Peridinium gatunense: (78) living cell, (n) nucleus, LM; (79) empty theca in ventral view, LM; (80) ventral view, SEM; (81) apical view, SEM; (82) antapical view, SEM. Scale bars $10 \mu \mathrm{m}$.
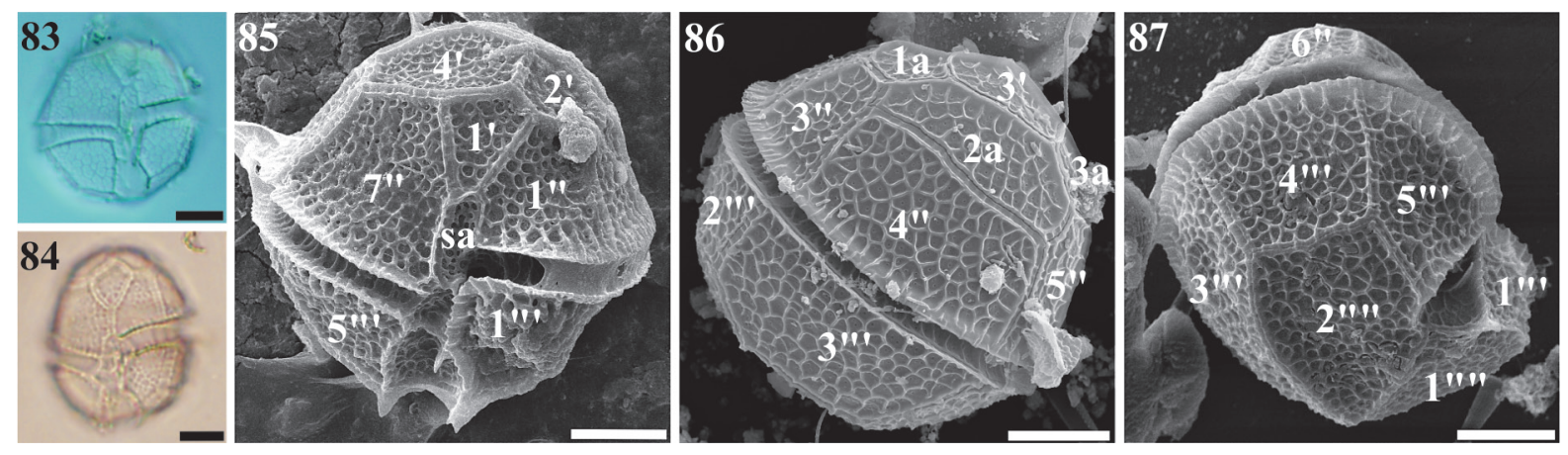

Figs 83-87. Peridinium volzii var. Cinctiforme: (83) empty theca in ventral view, LM; (84) theca with atypical variation in tabulation, showing 1" linked to 7", LM; (85) ventral view, SEM; (86) dorsal view, SEM; (87) antapical view, SEM. Scale bars $10 \mu \mathrm{m}$.

Distribution in Brazil: the only record of this species in Brazilian waters is from Amazonas (UHERKovICH \& RAI 1979) as 'P. elpatiewskyi forma (“minor")'. $P$. pygmaeum was also reported for the same region (Uherkovich 1976, 1981; Uherkovich \& Rai 1979). This is the first record for southern Brazil.

Peridiniopsis cf. kevei Grigorszky et VASAS in GrigORSZKY (1999, p. 31, figs 23, 24, SEM plates: figs 3-10) Figs 69-77

Bi-conical cells; epi- and hypotheca equal in size; hypotheca with a horn-like projection of variable length, formed by the antapical plates; cingulum almost circular, with short and indented lists; narrow and shallow sulcus, not reaching the antapex; apical pore projected; numerous brown-golden plastids; plates smooth, with scattered pores; plate formula: Po, X, 3', 1a, 6", ?c, ?s, 5"', 2"'. Length: 26-45.7 $\mu \mathrm{m}$; width: 23.5-38 $\mu \mathrm{m}$.

Occurrence: localities 7, 9, 17, 18. It was observed at various periods of the year.

Comments: Peridiniopsis kevei has priority in relation to $P$. corillionii Leitão, Ten-Hage, Mascarell et Couté and P. rhomboides Krakhmalny, with basis in the valid publication of this name in GRIGORSZKY's thesis according to ICN (GryGorszky 1999, see also discussion in HANSEN \& FLAim 2007). The populations observed here had some important differences from the $P$. kevei recorded in Europe (GrigorszKY et al. 2001; Leitão et al. 2001; KrakhMalny 2002; Hansen \& Flaim et al. 2007). In P. kevei, cells are dorsoventrally flattened, plate ornamentation is reticulate and plate 1a is four-sided (GrigorszKY et al. 2001), while $P$. cf. kevei observed here was almost circular in the cingulum, it had smooth plates and plate 1a was fiveor six-sided, never quadrangular (Figs 71, 72, 75). Moreover, the apical pore in $P$. keve $i$ is usually hidden by elevated apical plates edges, with 3' margin often higher than 2' one, giving the impression that the pore is oriented to the left (Grigorszky et al. 2001; LeITÃo et al. 2001; Krakhmalny 2002). In P. cf. kevei, the apical plates borders formed a collar around of the apical pore complex (Figs 71, 75). Finally, the hypothecal extension observed in $P$. kevei is excentrical and formed by plate 1"'. In $P$. cf. kevei this prolongation is formed by the two antapical plates (Figs 73, 74). Such differences lead to uncertainties about the true relationship between these taxa. More detailed studies are need for an accurate identification of $P$. cf. kevei.

Distribution in Brazil: P. corillioni was cited for State of Goiás, but without figures or description (NABOUT \& Nogueira 2007). In South America, Iltis \& Couté (1984) recorded in Bolivia one taxon very similar in shape to our material, which they identify as "P. wisconsinense ?". No other record of $P$. kevei has been 
found. A more extensive survey of these forms is needed.

\section{Peridinium gatunense NygaARd in Ostenfeld \&} NygaARD (1925, p. 10, figs 5-10) Figs 78-82

Cells spherical, epi- and hypotheca equal in size; cingulum median, descending, often with wide lists; sulcus shallow, not extending into the epitheca; numerous golden-brown plastids throughout the cell; nucleus central; eyespot not observed; thick plates with reticulated surface, each reticule containing a pore; plate formula: 4', 3a, 7", ?c, ?s, 5'", 2"'. Length: 30-46.7 $\mu \mathrm{m}$; width: $36-51 \mu \mathrm{m}$.

Occurrence: localities $1,2,3,6,7,8,9,10,11,14$, $16,18,19,20,26,27,28,29,32,35,39$. This widely distributed species was present in all seasons.

Comments: the taxonomy of this worldwide distributed species has been very stable (PopovskÝ \& Pfiester 1990). Along its taxonomic history, six infraspecific taxa were described for $P$. gatunense, primarily differentiated by general shape, size, and plate ornamentation (LefĖvRe 1932; Krakhmalny et al. 2014). However, "P. gatunense var. zonatum (Playfair) LefÈVRe", a variety attributed to this species (Lefèvre 1932), is an improper combination, since P. zonatum (Playfair) Playfair 1920 is an earlier legitimate name in the same rank as P. gatunense (Art. 11.4, McNeILL et al. 2012). $P$. zonatum can be distinguished from $P$. gatunense by having more rounded cells, a narrower 1a plate, and plates ornamented by irregular ribs arranged side by side on each plate (Playfair 1912). Although the thecal ornamentation was not considered reliable to distinguish species by Popovský \& Pfiester (1990), it is not appropriate at this moment to make any nomenclatural change without studying the relationship of both taxa based on molecular data. To preserve stability in this name, for now we consider $P$. zonatum a separate species.

Distribution in Brazil: P. gatunense is the most recorded freshwater dinoflagellate in Brazil, found in all regions of the country (ODEBRECHT et al. 2015).

\section{Peridinium volzii var. cinctiforme M. LèFEVRe (1927,} p. 122) Figs 83-87

Round cells, dorsoventrally flattened; epi- and hypotheca equal in size; cingulum median, descending, often with wide lists; wide sulcus, extending into the epitheca; numerous golden-brown plastids throughout the cell (not shown); nucleus and eyespot not observed; thick plates ornamented with ridges that form a reticulum, each cell of the reticulum containing 1-2 pores; plate formula: 4', 3a, 7", ?c, ?s, 5'", 2'"'. Length: 36-54.8 $\mu \mathrm{m}$; width: 30.6-52 $\mu \mathrm{m}$.

Occurrence: localities 2, 7, 14, 17, 18, 25, 29, 35, 38 . It was observed at various periods of the year.

Comments: there are two varieties and five forms, besides the typical variety $(P$. volzii LeMmermann var. volzii). They are distinguished by the different sym- metry in plate 1', presence or not of spines in the hypotheca, plate ornamentation and general shape of the cell (Lefèvre 1932, Huber-Pestalozzi 1950). A revision of this group is needed using modern tools to establish the phylogenetic relationships among taxa. For now, only morphological features are used in the infraspecific differentiation, which is useful to record as accurately as possible the morphological details found in populations. In material from Paraná, $P$. volzii was identified at infraspecific level, as $P$. volzii var. cinctiforme, distinguished from typical $P$. volzii especially by the asymmetric shape of the upper margins of plate 1', due to the difference in size of adjacent plates 2' and 3' (LÈFEVRE 1932). This feature showed little variation in the studied populations. P. volzii has been often confused with $P$. willei HuITFELD-KAas, however these species are morphologically, ecologically (OLRIK 1992) and genetically (LogARES et al. 2007) distinct.

Distribution in Brazil: the majority of works that cite $P$. volzii do not use infraspecific level. The distribution of $P$. volzii varieties is therefore undetermined. $P$. volzii var. cinctiforme was confirmed in Minas Gerais (Borics et al. 2005) and in Rio de Janeiro (Huszar et al. 1988), São Paulo (Sant'Anna et al. 1989), and Rio Grande do Sul (FranCESCHINI 1992) taking into account the illustrations provided. Some records of $P$. willei in Brazilian freshwaters may correspond to $P$. volzii instead.

Tyrannodinium edax (A.J. Schilling) Calado (2011, p. 643, figs 1-3) Figs 88-94

Basionym: Glenodinium edax A.J. Schilling (1891, p. 206, pl. X, figs 23-24)

Elliptical cells; epitheca conical, similar size as the hypotheca; hypotheca round to conical, no spines observed; cingulum slightly descending; narrow sulcus, not extending onto the epitheca nor reaching the antapex; apical pore not protruded; plastids and eyespot absent; large nucleus located in hypocone and food items in epicone; plates smooth, with scattered pores; plate formula: Po, X, 4', 6", ?c, ?s, 5"', 2"'. Length: 18.7-29.1 $\mu \mathrm{m}$; width: $15.3-25.1 \mu \mathrm{m}$.

Occurrence: localities 2, 4, 6, 8, 14, 17, 18, 23, 27, 34, 41. It was observed at various times.

Comments: Tyrannodinium berolinense (LeMmermann) Calado, Craveiro, Daugbjerg et Moestrup, type species of the pfiesteracean freshwater genus Tyrannodinium Calado, Craveiro, Daugbierg et Moestrup, should be regarded as synonym of T. edax according to CALADO (2011).

Distribution in Brazil: this characteristic species is recorded for first time in Brazilian freshwaters.

\section{Immobile dinoflagellates}

Tetradinium javanicum G.A. KLEBS (1912, p. 408, 444, figs 11, pl. X, fig. 3) Figs 95-97

Tetrahedral cells, with 2 spine-like projections at each angle; one angle prolonged into a stalk ending in an 

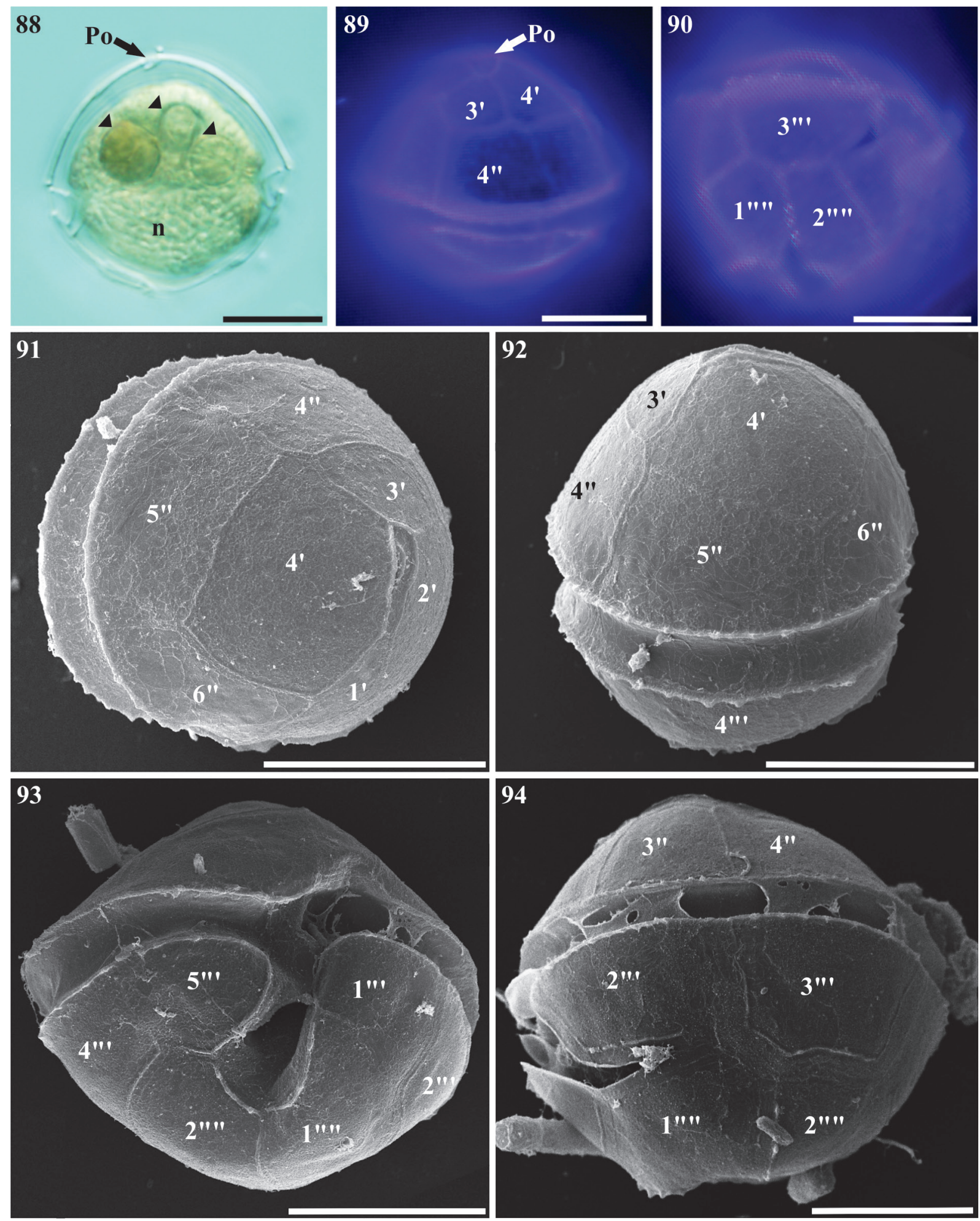

Figs 88-94. Tyrannodinium edax: (88) fixed cell, showing large nucleus (n), food vacuoles (arrowheads) and apical pore (Po, arrow), LM; (89, 90) tabulation of epi- and hypotheca, respectively, in epifluorescence LM; (91) apical view, SEM; (92) dorso-lateral view of epitheca, SEM; (93) hypotheca in ventral view, SEM; (94) hypotheca in lateral view, SEM. Scale bars $10 \mu \mathrm{m}$. 
adhesive disk, by which the cell attaches to filamentous green algae; numerous discoid green plastids throughout the cell. Length: 40.8-61.7 $\mu \mathrm{m}$; width: 20-34.2 $\mu \mathrm{m}$; stalk: 9.2-12.5 $\mu \mathrm{m}$.

Occurrence: only in locality 21 . This species has been found once in November 2011.

Comments: five species are validly published in $T e$ tradinium Klebs: T. javanicum, T. minus PASCHER, $T$. intermedium GEITLER, T. chiastosporum HARRIS and T. simplex PrescotT. Recognition of these species as distinct entities or as taxonomic synonyms varies with authors (Popovský \& Pfiester 1990, CArty 2014). In original publications, T. javanicum was characterized by having cells with two spines in each angle and attached by stalk (KLEBS 1912). T. minus was depicted with one spine in each angle (Popovský \& Pfiester 1990). T. intermedium was distinguished from $T$. javanicum in Popovský \& PfIESTER (1990) by having more concave sides, but this feature is not readily recognized in the illustrations. T. chiatosporum was characterized by having no stalk (HARRIS 1940), but it also seems to be variable in the same species. Finally, $T$. simplex is a small form, with one spine at each angle and only two plastids (Popovský \& Pfiester 1990). The phylogenetic relationships among them need to be revised. Our specimens fit $T$. javanicum circumscription, which is also the oldest name and the type species of the genus.

Distribution in Brazil: recorded from São Paulo (Bicudo \& Skvortzov 1968), Rio de Janeiro (Menezes 1995), and Rondônia (Albuquerque \& Menezes 1997). This is the first record from southern Brazil.

Stylodinium globosum G.A. KLEBS (1912, p. 410, 445, fig. 12 A-C) Fig. 98

Roundish cells, with one stalk ending in an adhesive disk by which the cell attaches to filamentous green algae; numerous yellowish-brown plastids throughout the cell. A large red body present in the region opposite to the stalk insertion. Length: $28.3 \mu \mathrm{m}$; width: 25.8 $\mu \mathrm{m}$; stalk: $10.8 \mu \mathrm{m}$.

Occurrence: only in locality 21 . This species was found once in November 2011.

Comments: a number of species and genera related to Stylodinium G.A. KLEBS were described, but, as in $\mathrm{Te}$ tradinium, there is no consensus on their relationships. According to BourRelly (1970) species can be distinguished by cell shape, stalk length and the morphology of plastids and pyrenoids. However, Popovský \& PFIESTER (1990) considered all to be a broad morphological variation of the species $S$. globosum. Our taxon fits the original concept of $S$. globosum (KLEBS 1912).

Distribution in Brazil: four species of Stylodinium were identified in the States of Rio de Janeiro and São Paulo: S. cerasiforme PASCHER, S. lindemannii BAUmeister, $S$. tarnum Baumeister (Bicudo \& Skvortzov 1968), and Stylodinium globosum (Menezes 1995). A new species of Dinopodiella PAscher, D. baumeisteri


Figs 95-97. Tetradinium javanicum, LM: (95, 96) living cells; (97) detail of the stalk attached to filamentous algae; (98) Stylodinium globosum, LM. Note a large red body (arrow). Scale bars $10 \mu \mathrm{m}$.

Bicudo et Skvortzov, was described from São Paulo (Bicudo \& Skvortzov 1968). The illustrations of these taxa in Bicudo \& Skvortzov (1968) apparently show morphological variants of $S$. globosum. This is the first record in southern Brazil.

This study presented new data about freshwater dinoflagellate diversity in southern Brazil. The Paraná flora, still largely unknown, revealed high species richness when compared to other Brazilian states with a high number of dinoflagellate records, including Rio de Janeiro, São Paulo, Minas Gerais, and Rio Grande do Sul (Odebrecht et al. 2015). We believe that the dinoflagellate flora of the Paraná is still far from complete, since a number of environments were not sampled. Twelve taxa are here cited for the first time in southern Brazil, and three of them are new records for Brazilian freshwaters. Dinoflagellates were particularly common in quarry lakes (especially Peridiniopsis spp.) and urban lakes, where taxa with more restricted occurrence (H. nasutum, G. uliginosa, P. centenniale and immobile taxa) were found. Finally, three taxa found in this study could not be precisely identified, namely two morphospecies into Parvodinium umbonatum/inconspicuum complex and Peridiniopsis cf. kevei, and more detailed studies are needed to understand the relationship among these taxa and those already described.

\section{ACKNOWLEDGEMENTS}

The authors thank Companhia Paranaense de Energia (Copel) and Lactec Institute for providing phytoplankton samples from hydroelectric power plant sites for this study; Dr. Priscila Tremarin for helping with LM and SEM photos; MSc. Mariana S. Pandeirada for help with dehydration and critical point techniques; and Electron Microscopy Center of UFPR for providing SEM analysis. Coordenação de Aperfeiçoamento de Pessoal de Nível Superior 
(CAPES) funded the first author during an internship in University of Aveiro (PDSE, Proc. N ${ }^{\circ}$ BEX 3718/14-0). FCT/MCT supported S. C. Craveiro (SFRH/BPD/68537/2010) grant from the financing program QREN-POPH/FSE - Tipologia 4.1 - Formação Avançada. GeoBioTec was funded by UID/GEO/04035/2013. The English language review was done by Cary Collett.

\section{REFERENCES}

Albuquerque, C. S. \& Menezes, M. (1997): Algas flageladas clorofiladas da área de influência da BR-364, Vilhena - Ouro Preto D'oeste, Sudeste do Estado de Rondônia, Brasil. - Hoehnea 24: 1-16.

Allman, G.J. (1854): On a species of Peridinea. - Proceedings of the Royal Irish Academy 6: 118-120.

Ascencio, E.; Rivera, P. \& Cruces, F. (2015): Morphology of Peridiniopsis elpatiewskyi (Ostenfeld) Bourrelly (Dinophyceae) found for the first time in Chilean inland waters. - Gayana Botánica 72: 42-46.

Bicudo, C.E.M \& Bicudo, R.M.T. (1967): Floating communities of algae in an artificial pond in the Parque do Estado, São Paulo, Brazil. - Journal of Phycology 3: 233-234.

Bicudo, C.E.M \& Bicudo, R.M.T. (1969): Algas da lagoa das Prateleiras, Parque Nacional do Itatiaia, Brasil. - Rickia 4: 1-40.

Bicudo, C.E.M \& Skvortzov, B.V. (1968): Contribution to the knowledge of Brazilian Dinophyceae - immobile genera. - Anais do XIX Congresso Nacional de Botânica: 31-39.

Bicudo, C.E.M \& Skvortzov, B.V. (1970): Contribution to the knowledge of Brazilian Dinophyceae - free-living unarmoured genera. - Rickia 5: 5-21.

Bicudo, C.E.M \& Ventrice, M.R. (1968): Algas do brejo da Lapa, Parque Nacional do Itatiaia, Brasil. - Anais do XIX Congresso Nacional de Botânica: 3-30.

Boltovskoy, A. (1999): The genus Glochidinium gen. nov., with two species: $G$. penardiforme comb. nov. and G. platygaster sp. nov. (Peridiniaceae). - Grana 38: 98-107.

Borics, G.; Grigorszky, I.; PadisÁk, J.; Barbosa, F.A.R. \& DomA, Z.Z. (2005): Dinoflagellates from tropical Brazilian lakes with description of Peridinium brasiliense sp. nova. - Algological Studies 118: 47- 61.

Bourrelly, P. (1970): Les algues d'eau douce. Initiation à la systématique. Tome III: Les algues bleues et rouges, les Eugléniens, Peridiniens et Cryptomonadines. 512 pp, Boubée \& Cie, Paris VI.

CAladdo, A.J. (2011): On the identity of the freshwater dinoflagellates Glenodinium edax, with a discussion on the genera Tyrannodinium and Katodinium, and the description of Opisthoaulax gen. nov. - Phycologia 50: 641-649.

Calado, A. J.; Craveiro, S.C.; Daugbjerg, N. \& Moestrup, Ø. (2009): Description of Tyrannodinium gen. nov., a freshwater dinoflagellate closely related to the marine Pfiesteria-like species. - Journal of Phycology 45: 1195-1205.

Cardoso, L.S.; Fagundes, P.B. \& Becker, V. (2010): Spatial and temporal variations of Dinophyceae in subtropical reservoirs in Southern Brazil. - Hydrobiologia 654: 205-214.

Cardoso, L.S. \& Torgan, L.C. (2007): Dinoflagelados em diversos habitats e hidroperíodos na zona costeira do sul do Brasil. - Acta Botanica Brasilica 21: 411-419.

CARTy, S. (2008): Parvodinium gen. nov. for the umbonatum group of Peridinium (Dinophyceae). - Ohio Journal of Science 108: 103-107.

CARTY, S. (2014): Freshwater dinoflagellates of North America. -260 pp., Cornell University Press, Ithaca.

CArty, S. \& Cox, E.R. (1986): Kansodinium gen. nov. and Durinskia gen. nov.: two genera of freshwater dinoflagellates (Pyrrhophyta). - Phycologia 25: 197-204.

Cavalcante, K.P.; Zanotelli, J.C.; Müller, C.C.; Scherer, K.D.; Frizzo, J.C.; Ludwig, T.A.V. \& CARdoso, L.S. (2013): First record of expansive Ceratium Schrank, 1793 species (Dinophyceae) in southern Brazil, with notes on their dispersive patterns in Brazilian environments. - Check List 9: 862-866.

Couté, A.; Perrette, C. \& Chomérat, N. (2012): Three Dinophyceae from Clipperton Island lagoon (eastern $\mathrm{Pa}$ cific Ocean), including a description of Peridiniopsis cristata var. tubulifera var. nov. - Botanica Marina 55: 59-71.

Craveiro, S.C.; Moestrup, Ø.; Daugbuerg, N. \& Calado, A.J. (2010): Ultrastructure and large subunit rDNAbased phylogeny of Sphaerodinium cracoviense, an unusual freshwater dinoflagellate with a novel type of eyespot. - The Journal of Eukaryotic Microbiology 57: 568-585.

Cunha, A.M. (1913): Contribuição para o conhecimento da fauna de protozoários do Brazil. - Memórias do Instituto Osvaldo Cruz 5: 101-122.

Cunha, A.M. (1916): Contribuição para o conhecimento da fauna de protozoários do Brazil IV. - Memórias do Instituto Osvaldo Cruz 8: 66-73.

CunHA, A.M. (1918): Contribuição para o conhecimento da fauna de protozoários do Brazil. - Memórias do Instituto Osvaldo Cruz : 192-193.

DADAY, E. (1905): Untersuchungen über die Süsswasser-Mikrofauna Paraguays. - Zoologica 44: 1-374.

Delazari-Barroso, A.; Sant'Anna, C.L. \& Senna, P.A.C. (2007): Phytoplankton from Duas Bocas Reservoir, Espírito Santo State, Brazil (except diatoms). Hoehnea 34: 211-229.

Dodge, J.D. \& Crawford, R.M. (1969): The fine structure of Gymnodinium fuscum (Dinophyceae). - New Phytologist 68: 613-618.

Domingos, P. \& Menezes, M. (1998): Taxonomic remarks on planktonic phytoflagellates in a hypertrophic tropical lagoon (Brazil). - Hydrobiologia 369/370: 297-313.

Elbrächter, M. \& Meyer, B. (2001): Plate pattern variability and plate overlap in a clonal culture of the freshwater dinoflagellate Peridinium umbonatum STEIN species complex (Dinophyceae). - Neues Jahrbuch für Geologie und Paläontologie/Abhandlungen 219: 221-227.

Fawcett, R.C. \& Parrow, M.W. (2012): Cytological and phylogenetic diversity in freshwater Esoptrodinium Bernardinium species (Dinophyceae). - Journal of Phycology 48: 793-807.

Franceschini, I.M. (1992): Algues d'eau douce de Porto Alegre, Brésil (les Diatomophycées exclues). - In: Kies, L. \& Schnetter, R. (eds): Bibliotheca Phycologica, Band 92. - 81 pp., J. Cramer, Berlin.

Fritz, L. \& TrIEMER, R.E. (1985): A rapid simple technique utilizing calcofluor white M2R for the visualization of dinoflagellate thecal plates. - Journal of Phycol- 
ogy 21: 662-664.

Garcia-Baptista, M. (1993): Psammic algae from Praia Azul, Brazil. - In: Kies, L. \& Schnetter, R. (eds): Bibliotheca Phycologica, Band 94. - 167 pp., J. Cramer, Berlin.

GrYgorszKY, I. (1999): A magyarországi Dinophyta fajok taxonómiájának, chorológiájának és ökológiájának vizsgálata. - 143 pp. Kossuth Egyetemi Kiadó, Debrecen.

Grigorszky, I.; Vasas, F.; Borics, G.; Klee, R.; Schmidt, A. \& Borbéty, G. (2001): Peridiniopsis kevei sp. nov., a new freshwater dinoflagellate species (Peridiniaceae, Dinophyta) from Hungary. - Acta Botanica Hungarica 43: 163-174.

HallegraefF, G.M.; Bolch, C.J.S.; Hill, D.R.A.; Jameson, I.; LeRoi, J.M.; McMinn, A.; Murray, S.; Salas, M.F. \& SAunders, K. (2010): Algae of Australia. Phytoplankton of temperate coastal waters. $-421 \mathrm{pp}$. CSIRO Publishing, Melbourne.

Hansen, G. \& Flaim, G. (2007): Dinoflagellates of the Trentino Province, Italy. - Journal of Limnology 66: $107-141$.

Harris, T.M. (1940): A contribution to the knowledge of the British freshwater Dinoflagellata. - Proceedings of the Linnean Society of London 152: 4-33.

Hickel, B. (1988): Morphology and life cycle of Ceratium rhomvoides nov. sp. (Dinophyceae) from the lake Plußsee (Federal Republic). - Hydrobiologia 161: 49-54.

Hoppenrath, M.; Murray, S.A.; Chomérat, N. \& HoriguCHI, T. (2014): Marine benthic dinoflagellates - Unveiling their worldwide biodiversity. $-276 \mathrm{pp}$. E. Schweizerbart'sche Verlagsbuchhandlung, Stuttgart.

Huber-Pestalozzi， G. (1950): Das Phytoplankton des Süßwassers. 3 Teil Cryptophyceen, Chloromonadinen, Peridineen. -310 pp. E. Schweizerbart'sche Verlagsbuchhandlung, Stuttgart.

Huszar, V.L.M. (1996): Planktonic algae, other than desmids, of three Amazonian systems (Lake Batata, Lake Mussurá and Trombetas River), Pará, Brazil. Amazoniana 14: 37-73.

Huszar, V.L.M.; Nogueira, I.S. \& Silva, L.H.S. (1988): Fitoplâncton de rede da lagoa do Campelo, Campos, Rio de Janeiro, Brasil: uma contribuição a seu conhecimento. - Acta Botanica Brasilica 1: 209-219.

Iltis, A. \& Couté, A. (1984): Péridiniales (Algae, Pyrrhophyta) de Bolivie. - Revista de Hydrobiologia Tropical 17: 279-286

Jati, S.; Rodrigues, L.C.; Bortolini, J.C.; Paula, A.C.M.; Moresco, G.A.; Reis, L.M.; Zanco, B.F. \& Train, S. (2014): First record of the occurrence of Ceratium furcoides (Levander) Langhans (Dinophyceae) in the Upper Paraná River Floodplain (PR/MS), Brazil. Brazilian Journal of Biology 74: S235-S236.

KLEBS, G. (1912): Über Flagellaten- und Algen-ähnliche Peridineen. - Verhandlungen des Naturhistorischmedizinischen Vereins zu Heidelberg 11: 369-451.

KLEEREKoper, H. (1939): Estudo limnológico da represa de Santo Amaro em S. Paulo. Boletim da Faculdade de Filosofia e Ciências da Universidade de São Paulo 17: $1-151$

Koford, C.A. \& Swezy, O. (1921): The free-living unarmored Dinoflagellata. - Memoirs of the University of California 5: 1-562.

Krakhmalny, A.F. (2002): A new species of the genus Peri- diniopsis Lemm. (Peridiniales, Dinophyta). - International Journal on Algae 4: 51-58.

Krakhmalny, A.F.; Wasser, S.P.; Nevo, E. \& Kapitanchuk, L.M. (2014). New variety Peridinium gatunense Nygaard var. kinnereta Krachmalny (Dinophyta) from Lake Kinneret (Israel). - International Journal on Algae 24: 250-255.

LefÈvre, M. (1932): Monographie des espèces d'eau douce du genre Peridinium. - Archives de Botanique 2: $1-208$.

Leitão, M.; Ten-Hage, L.; Mascarell, G. \& Couté, A. (2001): Peridiniopsis corillionii sp. nova (Dinophyta), une nouvelle dinophycée d'eau douce de France responsable de marées rouges en rivière. - Algological Studies 102: 1-15.

LemmermanN, E. (1900): Ergebnisse einer Reise nach dem Pacific (H. Schauinsland 1896/97). Planktonalgen. - Abhandlungen herausgegeben vom Naturwissenschaftlichen Verein zu Bremen 16: 313-398.

Lemmermann, E. (1910): Algen I (Schizophyceen, Flagellaten, Peridineen). - Kryptogamenflora der Mark Brandenburg 3: 1-712.

LeVANDER, K.M. (1892): Notiz über die Täfelung der Schalenmembran des Glenodinium cinctum Ehbg. - Zoologischer Anzeiger 15: 405-408.

LEVANDER, K.M. (1894): Materialien zur Kenntniss de Wasserfauna in der Umgebung von Helsingfors, mit besonderer Berücksichtigung der Meeresfauna. I. Protozoa. - Acta Societatis pro Fauna et Flora Fennica 12: 3-115.

LindemanN, E. (1918): Untersuchungen über Süßwasserperidineen und ihre Variationsformen II. Archiv für Naturgeschichte 84: 121-194.

Logares, R.; Shalchian-Tabrizi, K.; Boltovskoy, A. \& Rengefors, K. (2007): Extensive dinoflagellate phylogenies indicate infrequent marine-freshwater transitions. - Molecular Phylogenetic and Evolution 45: 887-903.

Matsumura-Tundisi, T.; Tundisi, J.G.; Luzia, A.P. \& Degani, R.M. (2010): Occurrence of Ceratium furcoides (Levander) Langhans 1925 bloom at the Billings Reservoir, São Paulo State, Brazil. - Brazilian Journal of Biology 70: 825-829.

Mcneill, J.; Barrie, F.R.; Buck, W.R.; Demoulin, V.; Greuter, W.; Hawksworth, D.L.; Herendeen, P.S.; KnapP, S.; Marhold, K.; Prado, J.; Prud'homme Van Reine W.F.; Smith, G.F.; Wiersema, J.H. \& Turland, N.J. (2012): International Code of Nomenclature for algae, fungi, and plants (Melbourne Code). Regnum Vegetabile 154. - 240 pp. Koeltz Scientific Books, Königstein.

Menezes, M. (1995): Dinococcales (Dinophyceae) na região Sul do município do Rio de Janeiro, Brasil. Hoehnea 22: 17-26.

Menezes, M. \& Fernandes, V.O. (1990): Dinophyceae do Estado de Mato Grosso, MT, Brasil: municípios de Barra do Bugres, Cáceres, Chapada dos Guimarães, Porto Esperidião e Quatro Marcos. - Acta Botanica Brasilica 4: 21-30.

Menezes, M.; Fonseca, C.G. \& Nascimento, E.P. (1995): Algas de três ambientes de águas claras do município de Parintins, Estado do Amazonas, Brasil: Euglenophyceae e Dinophyceae. - Hoehnea 22: 1-15.

Menezes, M. \& Teixeira-JúnIor, E.C. (2001): Dinophyta. In: Menezes, M. \& Dias, I.C.A. (eds): Biodiversidade 
de algas de ambientes continentais do Estado do Rio de Janeiro. Série Livros 9: - pp. 105-109, Museu Nacional, Rio de Janeiro.

Mertens, K.N.; Takano, Y.; Yamaguchi, A.; Gu, H.; Bogus, K.; Kremp, A.; Bagheri, S.; Matishov, G. \& MatSUOKA, K. (2015): The molecular characterization of the enigmatic dinoflagellate Kolkwitziella acuta reveals an affinity to the Excentrica section of the genus Protoperidinium. - Systematics and Biodiversity 13: 509-524.

Meyer, B. \& Elbrächter, M. (1996): Proposal to conserve the name Peridinium elpatiewskyi (Dinophyceae) with a conserved type. - Taxon 45: 531-532.

Meyer, B.; Rai, H. \& Cronberg, G. (1997): The thecal structure of Peridiniopsis amazonica spec. nov. (Dinophyceae), a new cyst-producing freshwater dinoflagellate from Amazonian floodplain lakes. - Nova Hedwigia 65: 365-375.

Möвıus, M. (1889): Bearbeitung der von H. Schenck in Brasilien gesammelten Algen. - Hedwigia 28: 309358.

Moestrup, Ø. \& DaugbJerg, N. (2007): On dinoflagellate phylogeny and classification. - In: Brodie, J. \& LEWIS, J. (eds): Unravelling the algae. The past, present and future of algal systematics. The Systematics Association Special Volume Series 75. - pp. 215-230, CRC Press, Boca Raton.

Nabout, J.C. \& Nogueira, I.S. (2007): Spatial and temporal dynamics of phytoplankton functional group in a blocked valley (Brazil). - Acta Limnologica Brasiliensia 19: 305-314.

Odebrecht, C.; Menezes, M. \& Cardoso, L. (2015): Dinophyceae. - In: Lista de espécies da Flora do Brasil. Jardim Botânico do Rio de Janeiro: http://floradobrasil.jbrj.gov.br/jabot/floradobrasil/FB98853.

Oliveira, H.S.B.; Moura, A.N. \& Cordeiro-AraúJo, M.K. (2011): First record of Ceratium Shrank, 1973 (Dinophyceae: Ceratiaceae) in freshwater ecosystems in the semiarid region of Brazil. - Check List 7: 626-628.

OlRIK, K. (1992): Ecology of Peridinium willei and P. volzii (Dinophyceae) in Danish lakes. - Nordic Journal of Botany 12: 557-568.

Pandeirada, M.S.; Craveiro, S.C. \& Calado, A.J. (2013): Freshwater dinoflagellates in Portugal (W Iberia): a critical checklist and new observations. - Nova Hedwigia 97: 321-348.

Pearce, I. \& Hallegraeff, G.M. (2004): Genetic affinities, ecophysiology and toxicity of Prorocentrum playfairii and $P$. foveolata (Dinophyceae) from Tasmanian freshwaters. - Phycologia 43: 271-281.

Penard, E. (1891): Les Péridiniacées du Léman. - Bulletin des Travaux de la Société Botanique de Genève 6: $1-72$.

Playfair, G.I. (1912): Plankton of the Sydney water-supply. - Proceedings of the Linnean Society of New South Wales 37: 512-552.

Playfair, G.I. (1920): Peridineae of New South Wales. - Proceedings of the Linnean Society of New South Wales 44: 793-818, pls XLI-XLIII.

PopovskÝ, J. \& Pfiester, L.A. (1990): Dinophyceae (Dinoflagellida). - In: Ettl, H.; Gerloff, J.; Heynig, H. \& Mollenhauer, D. (eds): Sußwasserflora von Mitteleuropa, Band 6. - 272 pp., Gustav Fischer Verlag, Sttugart.
ProwazeK, S. (1910): Contribuição para o conhecimento da fauna de protozoários do Brazil. - Memórias do Instituto Oswaldo Cruz 2: 149-158.

Santos-Wisniewski, M.J.; Silva, L.C.; Leone, I.C.; LAUDARES-SILVA, R. \& Rocha, O. (2007): First record of the occurrence of Ceratium furcoides (Levander) Langhans 1925, an invasive species in the hydroelectricity power plant Furnas Reservoir, MG, Brazil. Brazilian Journal of Biology 67: 791-793.

Sant'Anna, C.L.; Azevedo, M.T.P. \& Sormus, L. (1989): Fitoplâncton do lago das Garças, Parque Estadual das Fontes do Ipiranga, São Paulo, SP, Brasil: estudo taxonômico e aspectos ecológicos. - Hoehnea 16: 89-131.

SAnT'AnNA, C.L.; Xavier, M.B. \& Sormus, L. (1988): Estudo qualitativo do fitoplâncton da repressa de Serraria, Estado de São Paulo, Brasil. - Revista Brasileira de Biologia 48: 83-102.

Schiller, J. (1937): Dinoflagellatae (Peridineae). Teil 2. - In: Kolkwitz, R. (ed.): Rabenhort's Kryptogamen-Flora von Deutschland, Österreich und der Schweiz. Band 10. - 589 pp., Akademische Verlagsgesellschaft M.B.H., Leipzig.

SEnZAKI, S. \& Horiguchi, T. (1994): A taxonomic survey of freshwater dinoflagellates of Nagano Prefecture, Japan. - Japanese Journal of Phycology 42: 29-42.

StEIN, F. (1883): Der Organismus der Infusionsthiere nach eigenen Forschungen in systematischer Reihenfolge. III. Abtheilung. II. Hälfte. Die Naturgeschichte der arthrodelen Flagellaten. Einleitung und Erklärung der Abbildungen. - 30 pp., Wilhelm Engelmann, Leipzig.

TAKAno, Y. \& Horiguchi, T. (2004): Surface ultrastructure and molecular phylogenetics of four unarmored heterotrophic dinoflagellates, including the type species of the genus Gyrodinium (Dinophyceae). - Phycological Research 52: 107-116.

Takano, Y.; Yamaguchi, H.; Inouye, I.; Moestrup, Ø. \& Horiguchi, T. (2014): Phylogeny of five species of Nusuttodinium gen. nov. (Dinophyceae), a genus of unarmoured kleptoplastidic dinoflagellates. - Protist 165: 759-778.

Tardio, M.; EllegaArd, M.; Lundholm, N.; SAngiorgi, F. \& Di Giuseppe, G. (2009): A hypocystal archeopyle in a freshwater dinoflagellate from the Peridinium umbonatum group (Dinophyceae) from Lake Nero di Cornisello, South Eastern Alps, Italy. - European Journal of Phycology 44: 241-250.

Thompson, R.H. (1947): Fresh-water dinoflagellates of Maryland. Publication $n^{\circ}$ 67. -28 pp., Chesapeak Biological Laboratory, Solomons Island.

Torgan, L.C.; Barreda, K.A. \& Santos, C.B. (2003): Catálogo das algas Cryptophyta, Heterokontophyta, Dinophyta, Haptophyta e Rhodophyta de águas continentais e costeiras do Rio Grande do Sul, Brasil. - Iheringia, Série Botânica 58: 227-250.

Uherkovich, G. (1976): Algen aus den Flüssen Rio Negro und Rio Tapajós. - Amazoniana 5: 465-515.

Uherkovich, G. (1981): Algen aus einigen Gewässern Amazoniens. - Amazoniana 7: 191-219.

Uherkovich, G. \& Franken, M. (1980): Aufwuchsalgen aus zentralamazonischen Regenwaldbächen. - Amazoniana 7: 49-79.

Uherkovich, G. \& RAI, H. (1979): Algen aus dem Rio Negro und seinen Nebenflüssen. - Amazoniana 6: 611-638. 
Uherkovich, G. \& Schmidt, G.W. (1974): Phytoplanktontaxa in dem zentralamazonischen Schwemmlandsee. Amazoniana 5: 243-283.

VILLERET, S. (1953): Quelques espèces d'Algues d'eau douce rares ou nouvelles. - Bulletin de la Société Botanique de France 100: 71-74.

WeSt, G.S. (1907): Report on the freshwater algae, including phytoplankton, of the Third Tanganyika Expedition conducted by Dr. W.A. Cunnington, 1904-1905. Journal of the Linnean Society of London, Botany 38: 81-197.

WoŁoszyńska, J. (1912): Das Phytoplankton einiger javanischer Seen mit Berücksichtigung des SawaPlanktons. - Bulletin International de l'Académie des Sciences de Cracovie, Série B: 649-709.

WoŁoszyńska, J. (1916): Polskie Peridineae słodkowodne. -
Bulletin International de l'Académie des Sciences de Cracovie, Série B: 260-285.

Wood, E.J.F. (1968): Dinoflagellates of the Caribbean Sea and adjacent areas. - 143 pp., University of Miami Press, Coral Gables.

Xia, S.; Zhang, Q.; Zhu, H.; Cheng, Y.; Liu, G. \& Hu, Z. (2013): Systematics of a kleptoplastidal dinoflagellate, Gymnodinium eucyaneum $\mathrm{Hu}$ (Dinophyceae), and its cryptomonad endosymbiont. - Plos One 8: e53820.

Zhang, Q.; Liu, G. \& Hu, Z. (2011): Morphological differences and molecular phylogeny of freshwater blooming species, Peridiniopsis spp. (Dinophyceae) from China. - European Journal of Protistology 47: 149-160.

(C) Czech Phycological Society (2017)

Received October 20, 2016

Accepted December 20, 2016 